\title{
Protein phosphorylation in spermatozoa motility of Acipenser ruthenus and Cyprinus carpio
}

\author{
levgeniia Gazo¹, Mariola A Dietrich², Gérard Prulière ${ }^{3}$, Anna Shaliutina-Kolešová, \\ Olena Shaliutina ${ }^{1}$, Jacky Cosson ${ }^{1}$ and Janet Chenevert $^{3}$ \\ ${ }^{1}$ University of South Bohemia in Čské Budějovice, Faculty of Fisheries and Protection of Waters, South Bohemian \\ Research Center of Aquaculture and Biodiversity of Hydrocenoses, Vodñany, Czech Republic, ${ }^{2}$ Department of \\ Gametes and Embryo Biology, Institute of Animal Reproduction and Food Research, Polish Academy of Sciences, \\ Olsztyn, Poland and ${ }^{3}$ Sorbonne Universités, UPMC Université Paris 06, CNRS, Laboratoire de Biologie du \\ Développement de Villefranche-sur-mer, Observatoire Océanologique, Villefranche sur-mer, France
}

Correspondence should be addressed to I Gazo; Email: gazo@frov.jcu.cz

\section{Summary}

Spermatozoa of externally fertilizing freshwater fish possess several different modes of motility activation. Spermatozoa of common carp (Cyprinus carpio L.) are activated by hypoosmolality, whereas spermatozoa of sterlet (Acipenser ruthenus) require Ca2+ and low concentration of $\mathrm{K}+$ for motility activation. Intracellular signaling differs between these two species as well, particularly in terms of utilization of secondary messengers (cAMP and $\mathrm{Ca} 2+$ ), and kinase activities. The current study was performed in order to determine the importance of protein phosphorylation and protein kinases for activation of sperm motility in carp and sterlet. Treatment with kinase inhibitors indicates that protein kinases A and C (PKA and PKC) participate in spermatozoa motility of both species. Immunodetection of phospho-(Ser/Thr) PKA substrates shows that phosphorylated proteins are localized differently in spermatozoa of carp and sterlet. Strong phosphorylation of PKC substrate was observed in flagella of sterlet spermatozoa, whereas in carp sperm, PKC substrates were lightly phosphorylated in the midpiece and flagella. Motility activation induced either phosphorylation or dephosphorylation on serine, threonine and tyrosine residues of numerous proteins in carp and sterlet spermatozoa. Proteomic methods were used to identify proteins whose phosphorylation state changes upon the initiation of sperm motility. Numerous mitochondrial and glycolytic enzymes were identified in spermatozoa of both species, as well as axonemal proteins, heat shock proteins, septins and calcium-binding proteins. Our results contribute to an understanding of the roles of signaling molecules, protein kinases and protein phosphorylation in motility activation and regulation of two valuable fish species, $C$. carpio and $A$. ruthenus.

Reproduction (2017) 154 653-673

\section{Introduction}

Spermatozoa motility represents a very important prerequisite leading to the contact and fusion between male and female gametes for fertilization. The development of spermatozoa motility is a complex process with two phases: a very rapid response to activating triggers, which occurs in the range of milliseconds, followed by a maintenance phase that involves a network of signaling pathways providing energy that lasts from a few seconds to several hours depending on the species (Dzyuba et al. 2015). In some freshwater fish species, such as the carp (Cyprinus carpio), very low water osmolality causes spermatozoa motility activation (Perchec Poupard et al. 1997), whereas in sturgeons activation can be achieved without osmolality variation (as compared with seminal fluid) through changes in ionic composition of the surrounding medium (Alavi \& Cosson 2006). Extracellular factors controlling sperm motility act on the flagellar motile apparatus, the axoneme, through signal transduction, cAMP and $\mathrm{Ca} 2+$ serving as second messengers. Mechanisms of intracellular signaling also vary among different species: in carp spermatozoa, motility activation does not require increased cAMP concentration (Krasznai et al. 2000); however, spermatozoa of sterlet depend on CAMP and Ca2+ ions for motility activation (Linhart et al. 2002, Alavi et al. 2011).

Since protein synthesis is switched off in spermatozoa before maturation (Baker 2016), one of the most important processes in sperm intracellular signaling involves post-translational modifications such as protein phosphorylation, which was extensively studied in human spermatozoa (O'Flaherty et al. 2006). Phosphorylation of proteins on serine/threonine (Ser/Thr) and tyrosine (Tyr) residues is controlled by the activity of protein kinases, while dephosphorylation of these residues is mediated by protein phosphatases. The balance of the kinase 
and phosphatase activities determines the majority of intracellular signaling pathways in spermatozoa (Aitken et al. 1995, Ray et al. 2012).

The second messengers, cAMP and calcium, affect sperm motility by regulating the cAMP-dependent protein kinase $\mathrm{A}$ (PKA) and the $\mathrm{Ca} 2+$-dependent protein kinase $\mathrm{C}$ (PKC) respectively. The contribution of PKA as a regulator of spermatozoa motility initiation was described for numerous species (Brokaw 1987, Inaba 2003). In salmonids, PKA is anchored near the outer arm dynein, where it is regulated by proteasomes, and is involved in phosphorylation of axonemal proteins (Inaba et al. 1998). In spermatozoa, one of the major known targets of this kinase is dynein (Hamasaki et al. 1991), a microtubule-dependent force-generating ATPase, which plays a key role in axonemal microtubule sliding (Visconti et al. 1995, Inaba 2003). The regulation of dynein-mediated sliding of the axonemal microtubule outer-doublet through protein phosphorylation/ dephosphorylation by PKA has been documented for different mammalian species (Lindemann \& Kanous 1989), as well as for rainbow trout, chum salmon, sea urchin (Inaba et al. 1999) and tunicate (Nomura et al. 2000). PKA is also involved in signaling processes on the outer side of mitochondria and can translocate into the mitochondria to phosphorylate proteins directly (Huttemann et al. 2007). The cAMP-independent phosphorylation of axonemal proteins during spermatozoa motility initiation has been reported as well for several fish species (Hayashi et al. 1987, Morita et al. 2003). However, it is not clear whether PKA is not involved in motility activation of those species or whether its activity is regulated by another pathway (Kohr et al. 2010). PKC, a serine/threonine kinase, has a key role during initiation and maintenance of motility in sea urchin spermatozoa (White et al. 2007). Conventional PKC isoforms have a requirement for $\mathrm{Ca} 2+$ for their activation (Newton 1995). Thus, activity of PKC is strongly associated with and controlled by Ca2+ signaling.

In addition to motility activation, fertilization processes regulated by protein phosphorylation include capacitation and the acrosome reaction in mammals, all of which are required for spermatozoon/egg fusion (O'Flaherty et al. 2006). Aside from dyneins, a few other phospho-proteins participating in fish sperm motility have been described (Inaba et al. 1998, Itoh et al. 2003, Zilli et al. 2016) but most of them are yet to be characterized. In particular, there is a lack of knowledge about the role of protein phosphorylation in spermatozoa of commercially important aquaculture fish species such as the sterlet (Acipenser ruthenus, a small sturgeon) and the common carp (Cyprinus carpio L.). In the present study, we address the changes in protein phosphorylation pattern associated with spermatozoa motility and identify potential kinase substrates in spermatozoa of these two species.

\section{Materials and methods}

\section{Reagents}

Protein kinase inhibitors staurosporine, $\mathrm{H}-89$, chelerythrine, Gö6983 and tyrphostin 23 were purchased from the SigmaAldrich Co. ReadyStrip IPG strips, protein markers and polyvinylidene difluoride (PVDF) membranes were from BioRad laboratories. Anti-phosphotyrosine, anti-phosphoserine, anti-phosphothreonine and anti-PKC polyclonal antibodies produced in rabbit were from Abcam. Phospho-(Ser/Thr) PKA substrate, phospho-(Ser) PKC substrate and PKA C- $\alpha$ polyclonal antibodies produced in rabbit and HRP-conjugated goat antirabbit IgG were purchased from Cell Signaling Technology (Biotech A.S., Prague, Czech Republic).

\section{Ethics}

Manipulations with animals were performed according to authorization for breeding and delivery of experimental animals (Reference number: 44218/2015-MZE-17214 17OZ14202/2015-17214, valid from 17th August 2015 for 5 years) and the authorization for the use of experimental animals (Reference number: 2293/2015-MZE-17214 16OZ22302/2014-17214, valid from 22th January 2015 for 5 years) issued to the Faculty of Fisheries and Protection of Waters, University of South Bohemia by Ministry of Agriculture of the Czech Republic.

\section{Broodstock handling and sperm collection}

Sperm was obtained from adult common carp (Cyprinus carpio L., $n=6$; body weight: $2-3 \mathrm{~kg}$ ) and sterlet (Acipenser ruthenus, $n=6$; body weight, $0.5-2 \mathrm{~kg}$ ) reared in the aquaculture facility of the Research Institute of Fish Culture and Hydrobiology at the University of South Bohemia, Vodnany, Czech Republic. Before experimentation, fish were held in tanks at water temperature of $22^{\circ} \mathrm{C}$ for carp and $14-15^{\circ} \mathrm{C}$ for sterlet. Spermiation was stimulated by intramuscular injection of carp pituitary powder dissolved in $0.9 \%(\mathrm{w} / \mathrm{v}) \mathrm{NaCl}$ solution at $2 \mathrm{mg} / \mathrm{kg}$ body weight for carp and $5 \mathrm{mg} / \mathrm{kg}$ of body weight for sterlet, $24 \mathrm{~h}$ prior to stripping. Sperm samples from carp were obtained by abdominal massage and collected directly into $10 \mathrm{~mL}$ plastic syringes. Sterlet semen was collected from the urogenital papilla by aspiration through a plastic catheter (5-7 mm diameter) connected to a $20 \mathrm{~mL}$ syringe. Care was taken to avoid contamination with mucus, feces or water. Samples were stored on ice $\left(0-4{ }^{\circ} \mathrm{C}\right)$ in closed assay tubes prior to analysis. Spermatozoa concentration of each male was estimated microscopically (Olympus BX 41) at 20x using a Burker cell hemocytometer. Average spermatozoa concentration was $55.1 \pm 2.2 \times 109 / \mathrm{mL}$ for carp and $1.26 \pm 0.7 \times 109 / \mathrm{mL}$ for sterlet.

\section{Inhibitor treatment}

The following inhibitors were used: staurosporine (broad spectrum inhibitor of protein kinases), H-89 (PKA inhibitor), chelerythrine and Gö6983 (inhibitors of PKC) and tyrphostin 23 (PKT inhibitor). Separate sperm samples from each 
experimental male were centrifuged at $300 \mathrm{~g}$ for $30 \mathrm{~min}$ at $4{ }^{\circ} \mathrm{C}$ to remove seminal plasma. The resulting pellets were diluted in an immobilizing medium (IM). IM for carp was prepared according to Perchec and coworkers and contained $200 \mathrm{mM}$ $\mathrm{KCl}, 30 \mathrm{mM}$ Tris- $\mathrm{HCl}$, pH 8.0; IM for sterlet contained $20 \mathrm{mM}$ Tris, $30 \mathrm{mM} \mathrm{NaCl}$ and $2 \mathrm{mM} \mathrm{KCl}, \mathrm{pH}$ 8.5. Sperm was diluted to a final concentration of $5 \times 108$ cells $/ \mathrm{mL}$ (Perchec et al. 1995). Protein kinase inhibitors were first dissolved in dimethyl sulfoxide (DMSO) at $100 \mathrm{mM}$, except for chelerythrine, which was dissolved at $10 \mathrm{mM}$, and then diluted to desired concentrations with $\mathrm{IM}$, so that the final concentration of DMSO in incubation medium did not exceed $1 \%$. The sperm samples were pre-incubated at $4{ }^{\circ} \mathrm{C}$ for 5 min with the inhibitors in $\mathrm{IM}$, and then activated, as described below, in activation medium (AM) containing $5 \mathrm{mM} \mathrm{KCl}, 45 \mathrm{mM} \mathrm{NaCl}, 30 \mathrm{mM}$ Tris, $\mathrm{pH} 8.2$ for carp sperm and $10 \mathrm{mM}$ Tris, $10 \mathrm{mM} \mathrm{NaCl}, 1 \mathrm{mM}$ $\mathrm{CaCl} 2, \mathrm{pH} 8.5$ for sterlet; motility was recorded and analyzed as described below.

\section{Spermatozoa motility analysis}

The percentage of motile spermatozoa was determined after triggering sperm motility under dark-field microscopy (Olympus BX 50, Japan). For triggering motility, sperm in IM was diluted with $\mathrm{AM}$ at a final dilution of 1:5000 and then a drop was placed on a microscope slide. To prevent spermatozoa from sticking to the slide, $0.25 \%(\mathrm{w} / \mathrm{v})$ pluronic acid was included in AM. Spermatozoa motility was recorded with a CCD video camera (SONY SSCDC50AP, Japan) mounted on a microscope, using 20x magnification objective lens and illumination by a stroboscopic flash (ExposureScopeTM). The movements of the spermatozoa heads were analyzed using Olympus Microlmage software (version 4.0.1. for Windows with a special macro by Olympus C \& S). Briefly, spermatozoa head positions on five successive frames are assigned different colors: frame 1 red, frames 2-4 green and frame 5 blue. Those that moved were visible in three colors, while non-moving spermatozoa were white. The percent motile was calculated at $15 \mathrm{~s}$ post activation from the number of white and red cells. 20-40 spermatozoa were counted for each frame. Spermatozoa motility activation and measurement were obtained in triplicate for each sample.

\section{Sample preparation and protein extraction}

Samples for Western blotting and for two-dimensional protein analysis were prepared as follows: sperm pellets were diluted either with IM or with AM containing $5 \mathrm{mM} \mathrm{KCl}, 45 \mathrm{mM} \mathrm{NaCl}$, $30 \mathrm{mM}$ Tris, pH 8.2 for carp sperm and $10 \mathrm{mM}$ Tris, $10 \mathrm{mM}$ $\mathrm{NaCl}, 1 \mathrm{mM} \mathrm{CaCl} 2, \mathrm{pH} 8.5$ for sterlet at a dilution ratio of 1:50. Sperm samples were frozen in liquid nitrogen at different time points after motility activation $(4,10,30,60 \mathrm{~s}$ for carp; $4,30,60,120 \mathrm{~s}$ for sterlet) and stored at $-80^{\circ} \mathrm{C}$. Other sperm samples were pre-incubated at $4^{\circ} \mathrm{C}$ for $5 \mathrm{~min}$ with the inhibitors $\mathrm{H}-89(200 \mu \mathrm{M})$ or chelerythrine $(100 \mu \mathrm{M})$ in IM without sperm activation and frozen in liquid nitrogen.

Proteins were extracted from spermatozoa with lysis buffer (8M urea, $2 \mathrm{M}$ thiourea, 4\% CHAPS, 10\% w/v isopropanol, $0.1 \% \mathrm{w} / \mathrm{v}$ Triton X-100, $100 \mathrm{mM}$ dithiothreitol) containing phosphatase inhibitors ( $1 \mathrm{mM}$ sodium orthovanadate, $50 \mathrm{mM}$
EDTA, $1 \mathrm{mM}$ okadaic acid) and protease inhibitors $(100 \mathrm{mM}$ PMSF, $1 \mathrm{mg} / \mathrm{mL}$ pepstatin A, $5 \mathrm{mg} / \mathrm{mL}$ leupeptin). The bicinchoninic acid assay was used to determine the protein concentration in samples.

\section{One-dimensional SDS-PAGE separation}

For SDS-PAGE, $25 \mu \mathrm{g}$ of protein was loaded for each lane. Sperm proteins were added to sample buffer containing $65 \mathrm{mM}$ Tris, 10\% (v/v) glycerol, 2\% (w/v) SDS, 5\% (v/v) beta-mercaptoethanol and $1 \%$ bromophenol blue, and then heated for $3 \mathrm{~min}$ at $95^{\circ} \mathrm{C}$. Proteins were separated on a $12 \%$ acrylamide gel using the Bio-Rad Mini-PROTEAN vertical electrophoresis system.

\section{Two-dimensional electrophoresis}

For two-dimensional (2D) electrophoresis, proteins were extracted from immotile or from activated spermatozoa $(30 \mathrm{~s}$ post activation for carp sperm and $120 \mathrm{~s}$ for sterlet). The protein concentration was determined as described previously. Isoelectric focusing was done on ReadyStrip IPG strips $(\mathrm{pH}$ 3-10, 7 and $11 \mathrm{~cm}$ ) with PROTEAN IEF (Bio-Rad). A total of $150 \mu \mathrm{g}$ of protein in $200 \mu \mathrm{L}$ of rehydrating buffer (8M Urea, $2 \mathrm{M}$ Thiourea, 4\% CHAPS, $50 \mathrm{mM}$ dithiothreitol, $0.4 \%$ IPG buffer) was applied to each IPG strip. The following conditions were used for separation: active rehydration at $50 \mathrm{~V}$ for $14 \mathrm{~h}$; isoelectric focusing, $500 \mathrm{~V}$ for $1 \mathrm{~h}, 1000 \mathrm{~V}$ for $1 \mathrm{~h}, 3000 \mathrm{~V}$ for $1 \mathrm{~h}$ (gradient) and $8000 \mathrm{~V}$ for $2 \mathrm{~h}$ (gradient). After isoelectric focusing, IPG strips were equilibrated with a buffer containing $6 \mathrm{M}$ urea, $29.3 \%$ glycerol, $2 \%$ SDS, $75 \mathrm{mM}$ Tris- $\mathrm{HCl}(\mathrm{pH}$ 8.8 ) and $2 \%$ dithiothreitol for $15 \mathrm{~min}$, followed by a second equilibration with a solution containing $2.5 \%$ iodoacetamide instead of dithiothreitol for a further $15 \mathrm{~min}$. The strip was loaded in $0.5 \%$ agarose in running buffer for SDS-PAGE poured over a $12 \%$ acrylamide gel, and the proteins separated according to molecular weight by electrophoresis. Some gels were further used for Western blot analysis, others were stained with Coomassie Brilliant Blue R-250 to visualize protein spots.

\section{Western blot analysis}

After SDS-PAGE and 2D electrophoresis, gels were placed on polyvinylidene difluoride (PVDF) membranes and electrically transferred. The total amount of protein loaded and transferred was controlled before immunodetection by staining the membrane with $0.1 \%$ (w/v) Coomassie Brilliant Blue R-250 in isopropanol. Membranes were destained for $15 \mathrm{~min}$ in acetic acid/ethanol/water (1:5:4), washed with water and finally airdried. The membranes were then blocked by incubation with $5 \%(\mathrm{w} / \mathrm{v})$ non-fat milk in TBST $(0.1 \% \mathrm{v} / \mathrm{v}$ Tween-20, $20 \mathrm{mM}$ Tris, $150 \mathrm{mM} \mathrm{NaCl}\left(\mathrm{pH} \mathrm{7.6))}\right.$ for $1 \mathrm{~h}$ at $20^{\circ} \mathrm{C}$. The membranes were washed three times with TBST, and then incubated for $16 \mathrm{~h}$ at $4{ }^{\circ} \mathrm{C}$ with polyclonal antibodies to either phosphotyrosine, phosphoserine, a phosphothreonine, PKA, PKC, phospho-(Ser/ Thr) PKA substrates or phospho-(Ser) PKC substrates diluted $1: 1000$ in $5 \% \mathrm{w} / \mathrm{v}$ bovine serum albumin in TBST (BSA-TBST). Membranes were then washed and incubated with horseradish peroxidase-conjugated goat anti-rabbit $\lg$ (1:3000 in 3\% w/v 
BSA-TBST) for $1 \mathrm{~h}$ at $20^{\circ} \mathrm{C}$. Reacted proteins were detected either with $3,3^{\prime}, 5,5^{\prime}$ tetramethylbenzidine (TMB) liquid substrate (Sigma-Aldrich) or with ECL-plus (GE Healthcare). The relative intensity of each band was measured using ImageJ (NIH, Bethesda, MD, USA). Total protein staining was used as a loading control (Supplementary Fig. 1, see section on Supplementary Data given at the end of this article).

\section{Immunolabeling}

Motility was activated by adding AM to sperm in Eppendorf tubes at a dilution ratio of 1:500. After activation, spermatozoa were attached to slides pre-coated with $0.01 \% \mathrm{w} / \mathrm{v}$ poly-Llysine. After incubation for $1 \mathrm{~min}$ at $20^{\circ} \mathrm{C}$, the sperm were fixed with $4 \%$ formaldehyde in IM for $30 \mathrm{~min}$ and stored in a moist chamber. The fixed spermatozoa were rehydrated and permeabilized using TBST. The slides were incubated with blocking buffer ( $3 \%$ BSA-TBST) for $1 \mathrm{~h}$ at $20^{\circ} \mathrm{C}$ and then with primary antibodies to phosphotyrosine, phosphoserine, phosphothreonine, PKA, PKC, phospho-(Ser/Thr) PKA substrates or phospho-(Ser) PKC substrates (dilution of $1: 100$ ) in the blocking buffer for $16 \mathrm{~h}$ at $4^{\circ} \mathrm{C}$, followed by washing with TBST $(5 \mathrm{~min})$ at $20^{\circ} \mathrm{C}$. Samples were then incubated with Rhodamine Red-X-conjugated goat anti-rabbit IgG (Jackson ImmunoResearch Laboratories) at 1:200 dilution ratio for $2 \mathrm{~h}$ at $20^{\circ} \mathrm{C}$, washed with TBST ( $5 \mathrm{~min}$ ) at $20^{\circ} \mathrm{C}$ and mounted in $50 \%$ $\mathrm{v} / \mathrm{v}$ glycerol or in certain cases treated with TBST containing $1 \mu \mathrm{M}$ 4,6-diamidino-phenylindole (DAPI) before mounting. Slides were examined by fluorescent microscopy (Olympus BX50) at 60× magnification.

\section{In-gel digestion and mass spectrometry}

Gels were washed in water, and protein spots were cut from gels. The gel pieces were de-stained by incubation with $50 \% \mathrm{v} / \mathrm{v}$ acetonitrile in $50 \mathrm{mM}(\mathrm{NH} 4) \mathrm{HCO} 3$ for $15 \mathrm{~min}$. The gel pieces were treated with $5 \mathrm{~mL}$ of $50 \mathrm{mM}(\mathrm{NH} 4) \mathrm{HCO} 3$ containing $1 \mu \mathrm{g}$ of modified sequencing-grade trypsin and incubated for $12 \mathrm{~h}$ at $37^{\circ} \mathrm{C}$. After digestion, the gel pieces were immersed in $100 \mu \mathrm{L}$ of $0.1 \% \mathrm{v} / \mathrm{v}$ trifluoroacetic acid (TFA) in water for further peptide extraction. The peptides were concentrated and desalted using Zip-Tip pipette tips (Millipore), which had been first equilibrated by sequential washings with $100 \%$ acetonitrile, $50 \%$ acetonitrile- $0.1 \%$ TFA and $0.1 \%$ TFA in water. The sample was loaded on the Zip-Tip and contaminants were washed away with $0.1 \%$ TFA. Peptides were eluted with $2 \mu \mathrm{L}$ of $50 \%$ acetonitrile- $0.1 \%$ TFA in water. A $5 \mathrm{mg} / \mathrm{mL}$ solution of $\alpha$-cyano-4-hydroxycinnamic acid ( $\alpha$-CHCA) in $50 \%$ acetonitrile- $0.1 \%$ TFA was used as a matrix. One microliter of each sample was mixed with $1 \mu \mathrm{L}$ of freshly made CHCA matrix and spotted on a steel MALDI target plate (MT 34 Target Plate Ground Steel, Bruker Daltonics). Peptide samples were analyzed on a time-of-flight Autoflex-TOF/TOF mass spectrometer (MALDI-TOF-TOF, Bruker Daltonics, Bremen, Germany). The MS and MS/MS LIFT spectra of selected ions were collected and calibrated externally using monoisotpoic $[\mathrm{M}+\mathrm{H}]+$ ion peptide calibration standards (Bruker Daltonics) consisting of angiotensin II (1046.54), angiotensin I (1296.68), substance P (1347.73), bombesin (1619.82), ACTH clip 1 (2093.086), ACTH clip 18 (2465.19) and somatostatin 28
(3147.471). The MS peptide mass fingerprint (PMF) and fragment mass spectra (MS/MS) from each individual spot were combined and used to search against the NCBIr database using MascotServer (Matrix Sciences) with the following settings: cleavage enzyme: trypsin, max missed cleavages: 2 and mass tolerance mono: $50 \mathrm{ppm}$, fragment ion mass tolerance of $0.5 \mathrm{Da}$; parent ion mass tolerance of $200 \mathrm{ppm}$; alkylation of cysteine by carbamidomethylation as a fixed modification and oxidation of methionine as a variable modification. For the PMF and MS/MS ion search, statistically significant $(P \leq 0.05)$ matches by MASCOT were regarded as correct hits.

\section{Data analysis}

All measurements were conducted in triplicate. Normality and the homogeneity of variance of all data were first tested with the Kolmogorov test and the Bartlett test, respectively. Values are expressed as means \pm S.E. $(n=6)$. Spermatozoa motility and densitometry data were analyzed using the Kruskal-Wallis test. All analyses were performed at a significance level of 0.05 using STATISTICA, v. 9.0 software for Windows.

\section{Results}

\section{Effect of kinase inhibitors on motility of carp and sterlet spermatozoa}

The effect of kinase inhibitors on spermatozoa motility was assessed at $15 \mathrm{~s}$ post activation (see Materials and Methods, Spermatozoa motility analysis) (Table 1). Treatment of sperm with the broad spectrum kinase inhibitor staurosporine significantly decreased motility of sterlet spermatozoa starting from a concentration of $50 \mu \mathrm{M}$. In contrast, carp sperm motility was only barely affected at $100 \mu \mathrm{M}(17.5 \%$ inhibition compared to control) and decreased slightly at higher concentrations of inhibitor (Table 1).

The inhibitor of tyrosine kinase, tyrphostin 23 had no significant effect on spermatozoa motility in both species at all tested concentrations. On the other hand, treatment with the PKC inhibitor chelerythrine, inhibited motility of both species at $100 \mu \mathrm{M}$, and significantly decreased motility of carp spermatozoa at $10 \mu \mathrm{M}$. This result could not be repeated however when chelerythrine was replaced by Gö6983, another PKC inhibitor, which had almost no effect probably for permeability reasons. Motility of carp spermatozoa was affected by the inhibitor of PKA $(\mathrm{H}-89)$ at $50 \mu \mathrm{M}$; while motility of sterlet spermatozoa seemed little affected by this treatment even at $500 \mu \mathrm{M}$.

Since chelerythrine was able to block spermatozoa motility of both species, it allows us to suggest that PKC is involved in motility of sterlet and carp spermatozoa. On the other hand, the effect of $\mathrm{H}-89$ indicates that PKA is involved only in carp spermatozoa motility. Since inhibitor specificity is not perfect, further analyses were performed in order to clarify the role of PKA and PKC in spermatozoa of sterlet and carp. 
Table 1 The effect of kinase inhibitors on spermatozoa of sterlet (Acipenser ruthenus) and carp (Cyprinus carpio L.).

\begin{tabular}{|c|c|c|c|c|}
\hline Inhibitor & Function & $\begin{array}{c}\text { Tested } \\
\text { concentrations }\end{array}$ & Sterlet motility $(\%)^{i}$ & Carp motility $(\%)^{i}$ \\
\hline Control (IM, 1\% DMSO) & & & $80.2 \pm 3.62^{\mathrm{A}}$ & $79.5 \pm 7.054^{\mathrm{A}}$ \\
\hline \multirow[t]{4}{*}{ Staurosporine } & Broad spectrum inhibitor, ATP-site competitor & $200 \mu \mathrm{M}$ & & $49.7 \pm 5.38^{\mathrm{CD}}$ \\
\hline & & $100 \mu \mathrm{M}$ & $7.9 \pm 1.165^{\mathrm{D}}$ & $66.6 \pm 9.67^{\mathrm{AB}}$ \\
\hline & & $50 \mu \mathrm{M}$ & $67.8 \pm 5.034^{\mathrm{B}}$ & $68.6 \pm 4.074^{\mathrm{A}}$ \\
\hline & & $10 \mu \mathrm{M}$ & $72.6 \pm 8.37^{\mathrm{AB}}$ & $71.9 \pm 9.575^{\mathrm{A}}$ \\
\hline \multirow[t]{3}{*}{ Tyrphostin 23} & Receptor type protein tyrosine kinase (PTK) & $100 \mu \mathrm{M}$ & $76.9 \pm 0.29^{\mathrm{AB}}$ & $68.5 \pm 9.703^{\mathrm{A}}$ \\
\hline & & $50 \mu \mathrm{M}$ & $78.1 \pm 5.68^{\mathrm{A}}$ & $67.7 \pm 5.54^{\mathrm{AB}}$ \\
\hline & & $10 \mu \mathrm{M}$ & $80.5 \pm 4.67^{\mathrm{A}}$ & $74.7 \pm 4.83^{\mathrm{A}}$ \\
\hline \multirow[t]{3}{*}{ Go 6983} & Ca2+-dependent PKC $\alpha 1$ and $\beta 1$ & $100 \mu \mathrm{M}$ & $75.3 \pm 0.39^{\mathrm{AB}}$ & $68.5 \pm 9.192^{\mathrm{A}}$ \\
\hline & & $50 \mu \mathrm{M}$ & $77.8 \pm 7.94^{\mathrm{A}}$ & $69.1 \pm 6.4^{\mathrm{A}}$ \\
\hline & & $10 \mu \mathrm{M}$ & $79.1 \pm 6.94^{\mathrm{A}}$ & $70.8 \pm 5.89^{\mathrm{A}}$ \\
\hline \multirow[t]{3}{*}{ Chelerythrine } & PKC inhibitor & $100 \mu \mathrm{M}$ & $26.9 \pm 3.86^{\mathrm{C}}$ & $3.5 \pm 1.089^{\mathrm{F}}$ \\
\hline & & $50 \mu \mathrm{M}$ & $32.2 \pm 10.325^{\mathrm{C}}$ & $7.9 \pm 1.8^{\mathrm{E}}$ \\
\hline & & $10 \mu \mathrm{M}$ & $67.9 \pm 13.36^{\mathrm{B}}$ & $58 \pm 8.959^{C}$ \\
\hline \multirow[t]{5}{*}{$\mathrm{H}-89$} & ATP-site competitor for PKA & $500 \mu \mathrm{M}$ & $66.5 \pm 4.59^{B}$ & \\
\hline & & $200 \mu \mathrm{M}$ & $74.4 \pm 9.029^{A}$ & $32.4 \pm 3.8^{\mathrm{D}}$ \\
\hline & & $100 \mu \mathrm{M}$ & $83.6 \pm 0.53^{\mathrm{A}}$ & $58.2 \pm 11.678^{\mathrm{C}}$ \\
\hline & & $50 \mu \mathrm{M}$ & & $59.1 \pm 13.657^{\mathrm{BC}}$ \\
\hline & & $10 \mu \mathrm{M}$ & & $70.3 \pm 4.074^{\mathrm{A}}$ \\
\hline
\end{tabular}

Data represent mean values \pm S.E. Different letters indicate significant differences within a column (Kruskal-Wallis test, $P<0.05)$.

\section{Changes in protein phosphorylation status and subcellular localization of phospho-proteins after motility activation in carp and sterlet spermatozoa}

PKC substrates

Proteins were extracted from spermatozoa before and after motility activation and analyzed by immunoblot. Immunodetection with anti-PKC antibody confirmed the presence of PKC in spermatozoa of both species at $76 \mathrm{kDa}$ that correspond to PKC $\beta$ isoform (Fig. 1A). The antibody to phospho-(Ser) PKC substrates revealed that in sterlet spermatozoa, a protein of $110 \mathrm{kDa}$ was phosphorylated in immotile spermatozoa and during the entire motility period, decreasing slowly over time (Fig. 2A). In the presence of PKC inhibitor chelerythrine, this band was dephosphorylated in immotile spermatozoa (Fig. 2A, left lane). In carp, one protein of $63 \mathrm{kDa}$ was detected by the same antibody in immotile spermatozoa, disappeared after motility activation, and became phosphorylated again after $30 \mathrm{~s}$ of motility period (Fig. 2B). Chelerythrine completely blocked the phosphorylation of this band in immotile spermatozoa. Immunostaining of sterlet spermatozoa showed that the phospho-(Ser) PKC substrate antibody labeled flagella and midpiece (Fig. 2C). A similar distribution of phosphorylated protein was observed in carp spermatozoa using this antibody; however, the intensity of staining was lower (Fig. 2D). Immunostaining with anti-PKC antibody (Fig. 1C) showed that localization of the kinase matches the localization of phosphorylated substrates (Fig. 2C and D).

\section{PKA substrates}

Protein kinase A was detected in spermatozoa of sterlet and carp at $42 \mathrm{kDa}$ (Fig. 1B). Incubation with
phospho-(Ser/Thr) PKA substrate antibodies (Fig. 3A and B) revealed that 7 proteins changed their phosphorylation state after motility activation in spermatozoa of sterlet. While the $95 \mathrm{kDa}$ protein appears to be phosphorylated only in immotile sperm, the degree of phosphorylation increased following activation for the 6 other proteins (90, $57,55,43,38$ and $30 \mathrm{kDa}$ bands). The phosphorylation of the 57,55 and $43 \mathrm{kDa}$ proteins was sensitive to $\mathrm{H} 89$ inhibition. A different pattern of phosphorylation was observed for carp spermatozoa, for which 9 proteins changed their phosphorylation state. The 125, 49, 30 and $27 \mathrm{kDa}$ proteins were modified in a transient manner, with phosphorylation increasing at the beginning of the motility period and disappearing after $30 \mathrm{~s}$ of motility, suggesting a role for these phospho-proteins in motility activation rather than in its maintenance. The phosphorylation of the 90, 79, 62 and $45 \mathrm{kDa}$ proteins was maximal in immotile sperm and dropped significantly following activation. Finally, a $40 \mathrm{kDa}$ protein appeared phosphorylated only in immotile spermatozoa. Incubation of immotile carp spermatozoa with the inhibitor H89 led to dephosphorylation of almost all bands except the $79 \mathrm{kDa}$ protein.

Localization of phospho-(Ser/Thr) PKA substrates using immunolabeling and fluorescence microscopy showed that in sterlet, PKA substrates were concentrated in flagella and heads of immotile spermatozoa (Fig. 3C). After motility activation these phospho-proteins were observed on the sperm membrane. In immotile carp spermatozoa, PKA substrates were localized in the midpiece and appeared in flagella only after motility activation (Fig. 3D). Interestingly, results of immunolabeling in carp spermatozoa show increase in the level of protein phosphorylation on the spermatozoon flagella after motility activation, although this was not 
A

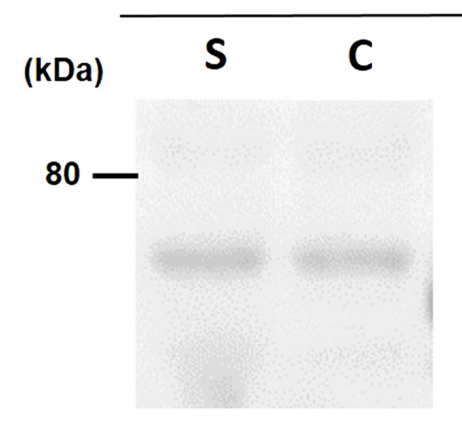

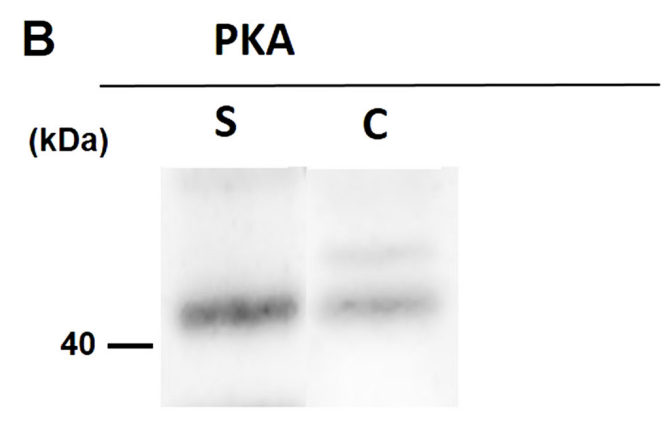

C
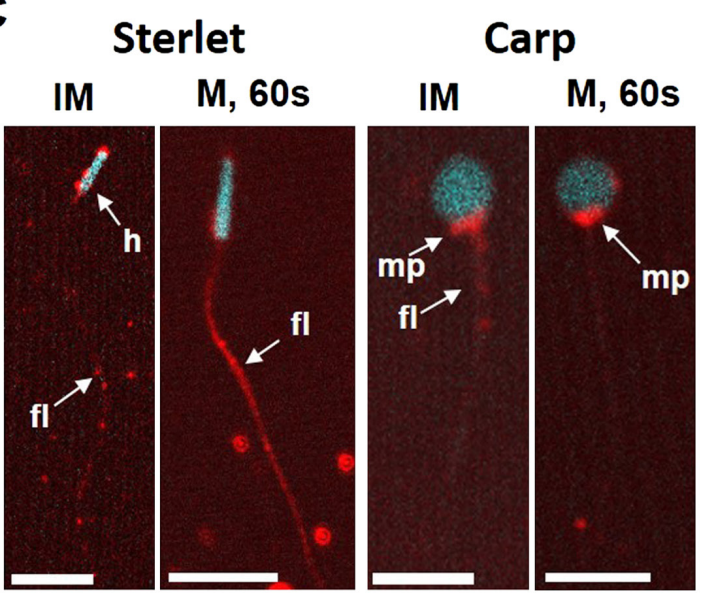

D

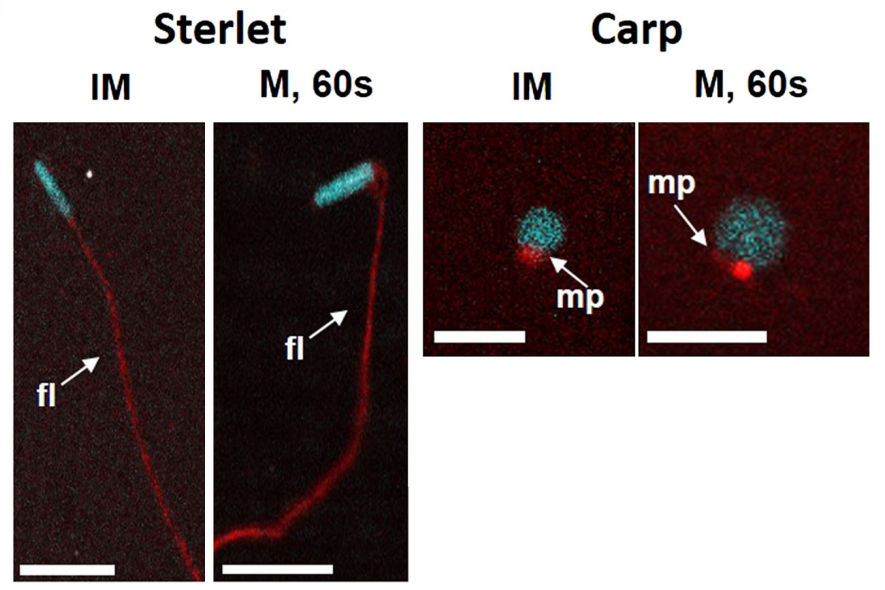

Figure 1 Reaction of anti-PKC and anti-PKA antibodies with spermatozoa from sterlet (S) and carp (C). (A and B) Western blots on proteins extracted from spermatozoa in immobilizing medium. Molecular weight markers (kDa) are on the left. (C and D) Immunolocalization of PKC and PKA in immotile (IM) and activated (M) spermatozoa which were attached to glass slides and fixed. Samples were stained with DAPI to visualize sperm DNA (in blue) and with Rhodamine Red-X-conjugated goat anti-rabbit secondary antibody to visualize PKC and PKA (in red). Labeled structures are indicated with white arrows: $\mathrm{h}=$ head of spermatozoon, $\mathrm{fl}=\mathrm{flagella}$, $\mathrm{mp}=\mathrm{midpiece}$. Bars represent approximately $10 \mu \mathrm{m}$.

observed with Western blots, which could be attributed to insolubility of some proteins in extraction medium.

In immotile sterlet spermatozoa, PKA was localized in the flagella of a spermatozoon (Fig. 1D), like the PKA substrates (Fig. 3C). In carp spermatozoa PKA was localized in the midpiece of a spermatozoon (Fig. 1D), similarly to phosphorylated PKA substrates (Fig. 3D).

\section{Protein phosphorylation on serine residue}

In both species, the phosphorylation pattern on three amino acid residues (serine, threonine and tyrosine) changed after motility activation (Figs 4, 5 and 6). Incubation with phosphoserine antibodies revealed 11 protein bands, which increased their phosphorylation state in spermatozoa of sterlet (Fig. 4A) (molecular weights of 98, 80, 62, 58, 55, 49, 45, 38, 30, 25 and $20 \mathrm{kDa}$ ). In carp spermatozoa (Fig. 4B), 10 proteins were found to be phosphorylated (125, 70, 60, 45, 43, 30 and $15 \mathrm{kDa})$ or dephosphorylated $(150,79,49 \mathrm{kDa})$ after motility activation.

Proteins with phosphorylated serine residue were observed in spermatozoa flagella and heads in both species (Fig. 4C and D). In carp spermatozoa, motility activation led to enhanced serine phosphorylation at the head of spermatozoa.

\section{Protein phosphorylation on tyrosine residue}

The Western blot analysis with antibodies to phosphotyrosine residues revealed that in sterlet spermatozoa, 6 proteins (of 120, 65, 55, 45, 25 and $20 \mathrm{kDa}$ ) appeared to increase in phosphorylation $4 \mathrm{~s}$ after motility activation and then were dephosphorylated by the end of motility period (Fig. 5A). Three protein bands (of 58, 48 and $39 \mathrm{kDa}$ ) were gradually dephosphorylated after motility activation compared to control (Fig. 5A). A total of 6 proteins were phosphorylated $(65,59,45$, and $35 \mathrm{kDa})$ or temporarily modified $(90,25 \mathrm{kDa})$ in carp spermatozoa (Fig. 5B).

Immunolocalisation of phosphotyrosine residue showed that in immotile sterlet spermatozoa, tyrosine phosphorylation occurred in a gradient manner along the flagellum, the signal disappearing toward the tip of the tail (Fig. 5C). In activated sperm, the fluorescent signal decreased in the flagellum but 


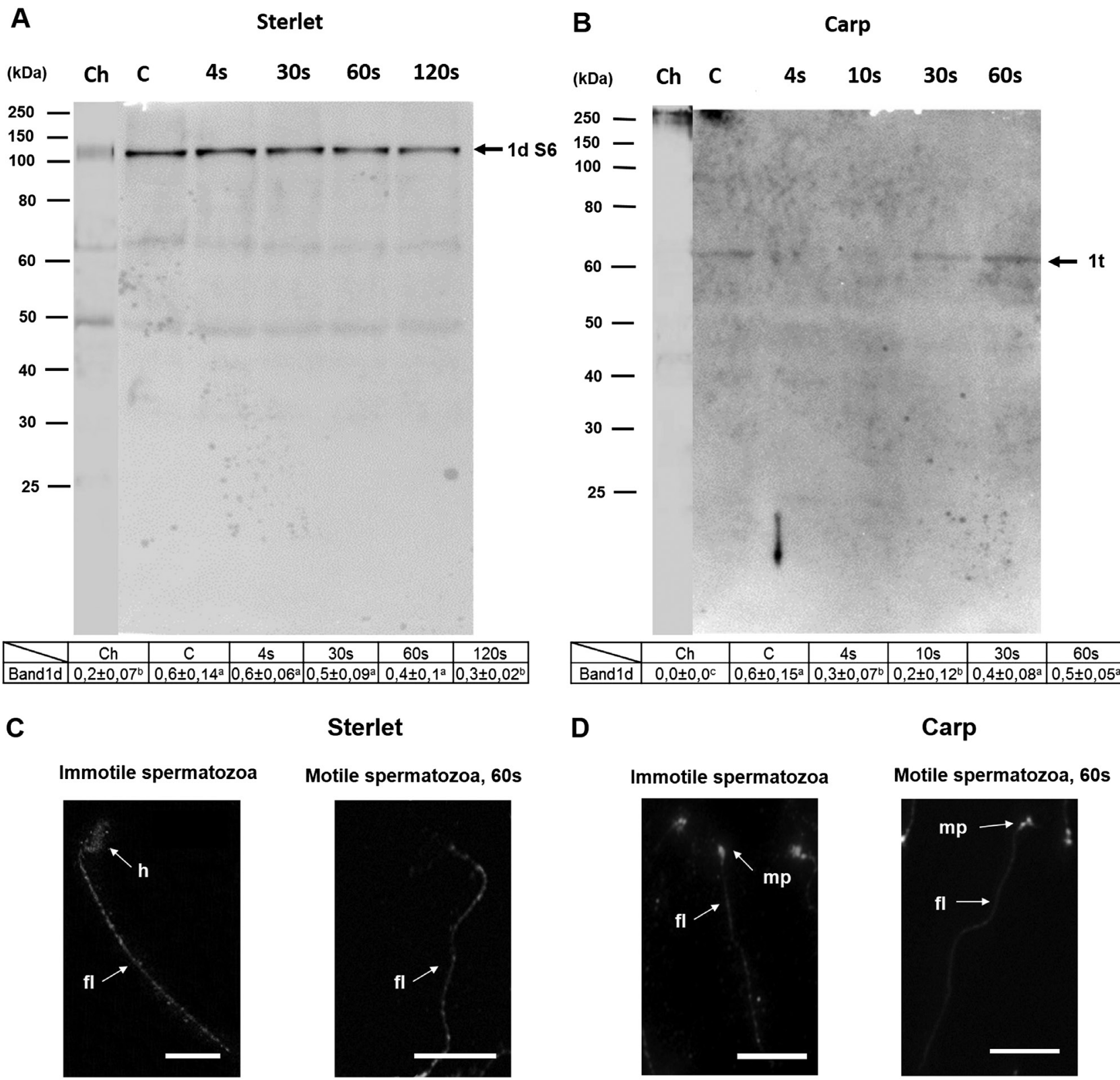

Figure 2 Reaction of phospho-(Ser) PKC substrate antibody with spermatozoa from sterlet (A and C) or carp (B and D). (A and B) Western blots on proteins extracted from spermatozoa either in immobilizing medium with (Ch) or without (C: control) PKC inhibitor chelerythrine, or at different times (in seconds) after motility activation. Arrows on the right indicate protein bands that changed phosphorylation state after motility activation: $d=$ decreased phosphorylation, $t=$ temporarily modified band. $S$ numbers correspond to spots which were identified by mass spectrometry and are listed in Table 2 (sterlet) or Table 3 (carp). Molecular weight markers (kDa) are on the left. Relative intensities of phosphorylated bands are summarized in tables below the Western blot images. Values are expressed as means \pm S.E. $(n=6)$. Small letters $(\mathrm{a}, \mathrm{b}$, c) indicate significant differences within a row (Kruskal-Wallis test, $P<0.05$ ). (C and D) Immunolocalization of PKC phospho-substrates in immotile and activated spermatozoa which were attached to glass slides and fixed: $\mathrm{h}=$ head of spermatozoon, $\mathrm{fl}=\mathrm{flagella}, \mathrm{mp}=\mathrm{midpiece}$. Bars represent approximately $10 \mu \mathrm{m}$.

increased in the head. In carp spermatozoa, however, tyrosine phosphorylation could be seen along the flagellum after motility activation, and in immotile spermatozoa, the majority of phosphorylated proteins were localized in the head of the spermatozoon (Fig. 5D).

\section{Protein phosphorylation on threonine residue}

In spermatozoa of sterlet, 3 proteins of 59, 51 and $42 \mathrm{kDa}$ increased phosphorylation on threonine residue up to $30 \mathrm{~s}$ after motility activation with subsequent dephosphorylation at the end of motility period 
A

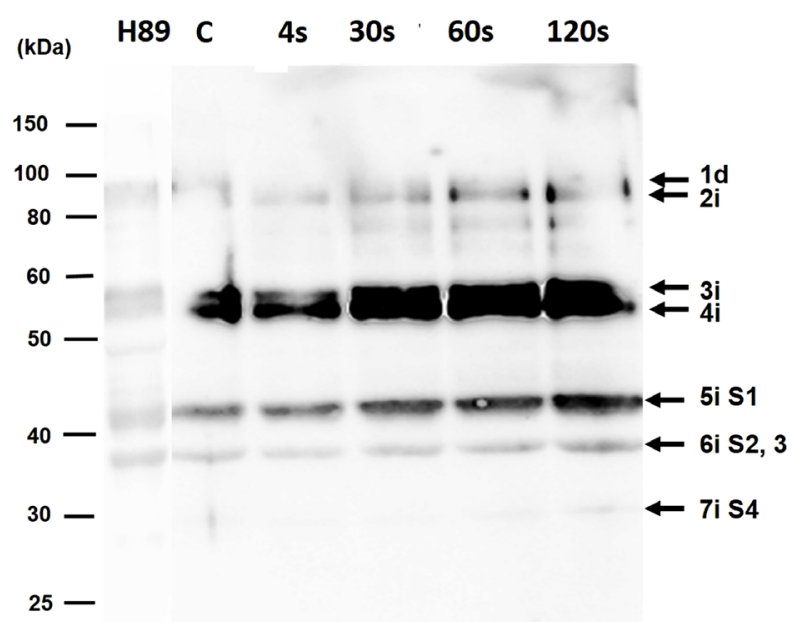

B

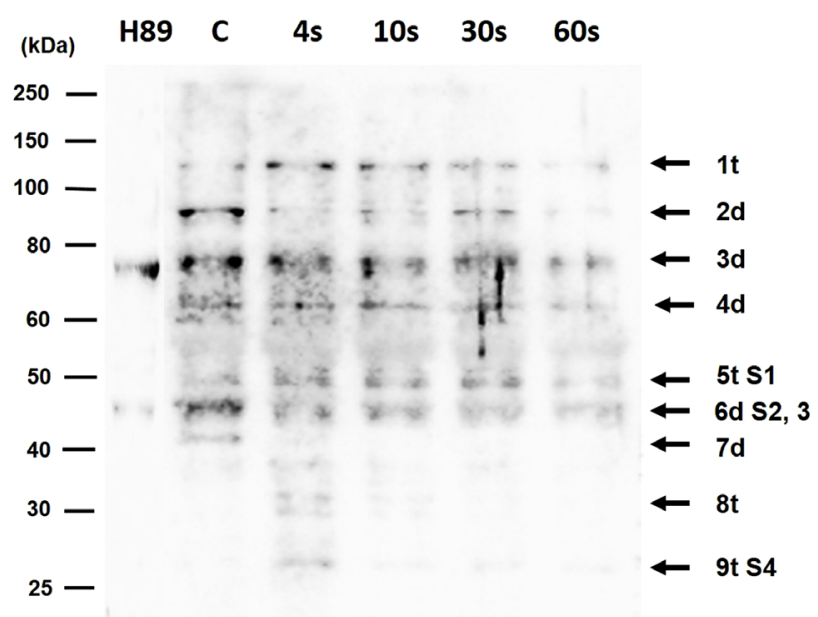

\begin{tabular}{|c|c|c|c|c|c|c|}
\hline & $\mathrm{H}-89$ & $\mathrm{C}$ & $4 \mathrm{~s}$ & $30 \mathrm{~s}$ & $60 \mathrm{~s}$ & $120 \mathrm{~s}$ \\
\hline Band $1 \mathrm{~d}$ & $0,1 \pm 0,0^{\mathrm{a}}$ & $0,1 \pm 0,02^{\mathrm{a}}$ & $0,0 \pm 0,0^{\mathrm{b}}$ & $0,0 \pm 0,01^{\mathrm{b}}$ & $0,08 \pm 0,06^{\mathrm{b}}$ & $0,07 \pm 0,05^{\mathrm{b}}$ \\
\hline Band $2 \mathrm{i}$ & $0,1 \pm 0,05^{\mathrm{b}}$ & $0,0 \pm 0,0^{\mathrm{a}}$ & $0,1 \pm 0,03^{\mathrm{b}}$ & $0,1 \pm 0,0^{\mathrm{b}}$ & $0,2 \pm 0,02^{\mathrm{b}}$ & $0,2 \pm 0,01^{\mathrm{c}}$ \\
\hline Band $3 \mathrm{i}$ & $0,1 \pm 0,05^{\mathrm{b}}$ & $0,3 \pm 0,1^{\mathrm{a}}$ & $0,2 \pm 0,04^{\mathrm{a}}$ & $0,5 \pm 0,3^{\mathrm{c}}$ & $0,5 \pm 0,05^{\mathrm{c}}$ & $0,6 \pm 0,02^{\mathrm{c}}$ \\
\hline Band $4 \mathrm{i}$ & $0,1 \pm 0,03^{\mathrm{b}}$ & $0,4 \pm 0,12^{\mathrm{a}}$ & $0,3 \pm 0,05^{\mathrm{a}}$ & $0,6 \pm 0,2^{\mathrm{a}}$ & $0,6 \pm 0,16^{\mathrm{a}}$ & $0,6 \pm 0,03^{\mathrm{c}}$ \\
\hline Band $5 \mathrm{i}$ & $0,2 \pm 0,07^{\mathrm{a}}$ & $0,3 \pm 0,07^{\mathrm{a}}$ & $0,3 \pm 0,01^{\mathrm{a}}$ & $0,5 \pm 0,05^{\mathrm{b}}$ & $0,6 \pm 0,04^{\mathrm{c}}$ & $0,6 \pm 0,07^{\mathrm{c}}$ \\
\hline Band 6i & $0,1 \pm 0,02^{\mathrm{a}}$ & $0,3 \pm 0,09^{\mathrm{a}}$ & $0,2 \pm 0,04^{\mathrm{a}}$ & $0,3 \pm 0,05^{\mathrm{a}}$ & $0,4 \pm 0,07^{\mathrm{a}}$ & $0,5 \pm 0,05^{\mathrm{b}}$ \\
\hline Band $7 \mathrm{i}$ & $0,0 \pm 0,0^{\mathrm{a}}$ & $0,0 \pm 0,01^{\mathrm{a}}$ & $0,0 \pm 0,0^{\mathrm{a}}$ & $0,1 \pm 0,01^{\mathrm{b}}$ & $0,2 \pm 0,1^{\mathrm{b}}$ & $0,2 \pm 0,05^{\mathrm{b}}$ \\
\hline
\end{tabular}

C

Sterlet

\begin{tabular}{|l|c|c|c|c|c|c|}
\hline & $\mathrm{H}-89$ & $\mathrm{C}$ & $4 \mathrm{~s}$ & $10 \mathrm{~s}$ & $30 \mathrm{~s}$ & $60 \mathrm{~s}$ \\
\hline Band 1t & $0,0 \pm 0,01^{\mathrm{b}}$ & $0,3 \pm 0,07^{\mathrm{a}}$ & $0,6 \pm 0,12^{\mathrm{c}}$ & $0,4 \pm 0,09^{\mathrm{a}}$ & $0,3 \pm 0,11^{\mathrm{a}}$ & $0,1 \pm 0,01^{\mathrm{b}}$ \\
\hline Band 2d & $0,0 \pm 0,0^{\mathrm{c}}$ & $0,6 \pm 0,1^{\mathrm{a}}$ & $0,2 \pm 0,06^{\mathrm{b}}$ & $0,2 \pm 0,05^{\mathrm{b}}$ & $0,2 \pm 0,08^{\mathrm{b}}$ & $0,0 \pm 0,0^{\mathrm{c}}$ \\
\hline Band 3d & $0,8 \pm 0,13^{\mathrm{a}}$ & $0,7 \pm 0,1^{\mathrm{a}}$ & $0,5 \pm 0,13^{\mathrm{a}}$ & $0,3 \pm 0,2^{\mathrm{b}}$ & $0,5 \pm 0,21^{\mathrm{a}}$ & $0,1 \pm 0,03^{\mathrm{b}}$ \\
\hline Band 4d & $0,0 \pm 0,0^{\mathrm{c}}$ & $0,3 \pm 0,07^{\mathrm{a}}$ & $0,2 \pm 0,1^{\mathrm{a}}$ & $0,1 \pm 0,07^{\mathrm{a}}$ & $0,1 \pm 0,06^{\mathrm{a}}$ & $0,1 \pm 0,01^{\mathrm{b}}$ \\
\hline Band 5t & $0,0 \pm 0,0^{\mathrm{c}}$ & $0,5 \pm 0,22^{\mathrm{a}}$ & $0,7 \pm 0,19^{\mathrm{a}}$ & $0,5 \pm 0,15^{\mathrm{a}}$ & $0,5 \pm 0,18^{\mathrm{a}}$ & $0,2 \pm 0,08^{\mathrm{b}}$ \\
\hline Band 6d & $0,1 \pm 0,04^{\mathrm{c}}$ & $0,9 \pm 0,1^{\mathrm{a}}$ & $0,4 \pm 0,12^{\mathrm{b}}$ & $0,3 \pm 0,1^{\mathrm{b}}$ & $0,3 \pm 0,09^{\mathrm{b}}$ & $0,2 \pm 0,01^{\mathrm{b}}$ \\
\hline Band 7d & $0,0 \pm 0,0^{\mathrm{c}}$ & $0,6 \pm 0,3^{\mathrm{a}}$ & $0,2 \pm 0,02^{\mathrm{b}}$ & $0,1 \pm 0,02^{\mathrm{b}}$ & $0,1 \pm 0,04^{\mathrm{b}}$ & $0,0 \pm 0,0^{\mathrm{c}}$ \\
\hline Band 8t & $0,1 \pm 0,01^{\mathrm{a}}$ & $0,2 \pm 0,16^{\mathrm{a}}$ & $0,7 \pm 0,08^{\mathrm{b}}$ & $0,3 \pm 0,06^{\mathrm{a}}$ & $0,1 \pm 0,1^{\mathrm{a}}$ & $0,1 \pm 0,0^{\mathrm{a}}$ \\
\hline Band 9t & $0,1 \pm 0,01^{\mathrm{a}}$ & $0,1 \pm 0,04^{\mathrm{a}}$ & $0,8 \pm 0,08^{\mathrm{b}}$ & $0,1 \pm 0,02^{\mathrm{a}}$ & $0,1 \pm 0,06^{\mathrm{a}}$ & $0,1 \pm 0,02^{\mathrm{a}}$ \\
\hline
\end{tabular}

D Carp
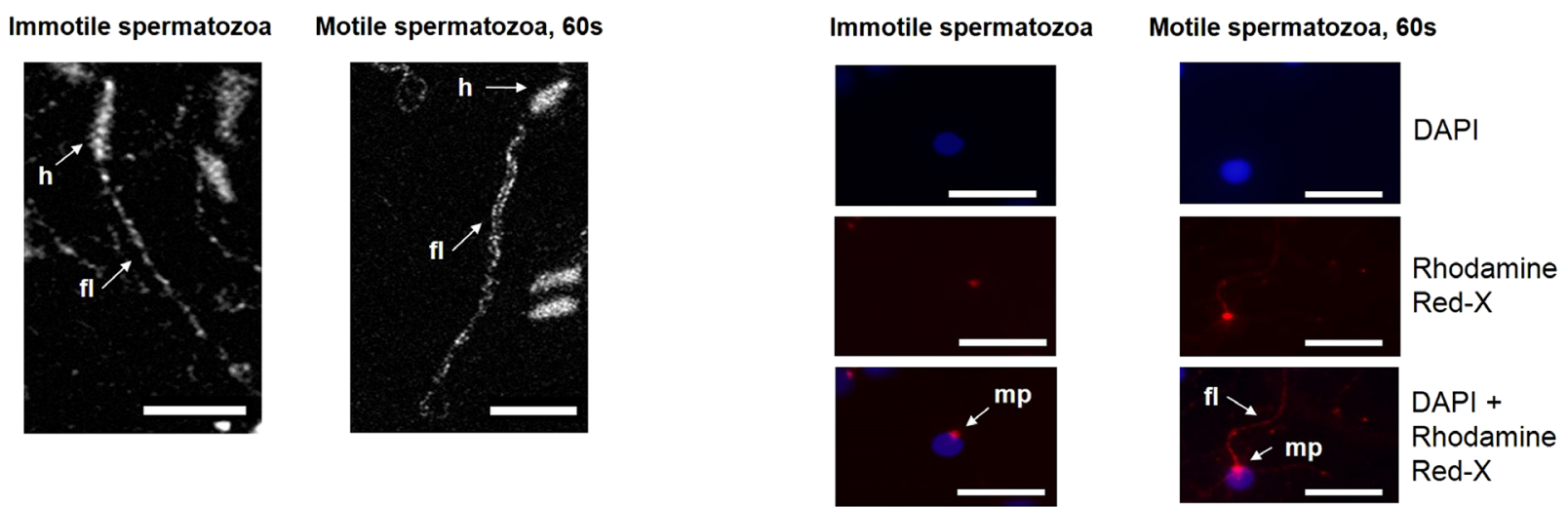

Figure 3 Reaction of phospho-(Ser/Thr) PKA substrate antibody with spermatozoa from sterlet (A and C) or carp (B and D). (A and B) Western blots on proteins extracted from spermatozoa either in immobilizing medium with (H89) or without (C: control) PKA inhibitor, $\mathrm{H}-89$ or at different times (in seconds) after motility activation. Arrows on the right indicate protein bands that changed phosphorylation state after motility activation: $\mathrm{i}=$ increased phosphorylation, $\mathrm{d}=$ decreased phosphorylation, $\mathrm{t}=$ temporarily modified band. $\mathrm{S}$ numbers correspond to spots which were identified by mass spectrometry and are listed in Table 2 (sterlet) or Table 3 (carp). Molecular weight markers (kDa) are on the left. Relative intensities of phosphorylated bands are summarized in tables below the Western blot images. Values are expressed as means \pm S.E. $(n=6)$.

Small letters $(\mathrm{a}, \mathrm{b}, \mathrm{c})$ indicate significant differences within a row (Kruskal-Wallis test, $P<0.05)$. (C and D) Immunolocalization of PKA phosphosubstrates in immotile and activated spermatozoa which were attached to glass slides and fixed. In D, the carp samples were stained with DAPI to visualize sperm DNA and with Rhodamine Red-X-conjugated goat anti-rabbit secondary antibody to visualize PKA phospho-substrates. $\mathrm{h}=$ head of spermatozoon, $\mathrm{fl}=$ flagella, $\mathrm{mp}=$ midpiece. Bars represent approximately $10 \mu \mathrm{m}$.

(Fig. 6A). In carp sperm, motility activation led to the dephosphorylation of a $56 \mathrm{kDa}$ protein (Fig. 6B) while three proteins of 60,45 and $27 \mathrm{kDa}$ were modified in a transient fashion like those in sterlet sperm (Fig. 6A). Overall, serine and threonine phosphorylation (Figs $3 \mathrm{~A}$ and $\mathrm{B}$ and $6 \mathrm{~A}$ and $\mathrm{B}$ ) did not completely correspond 
A

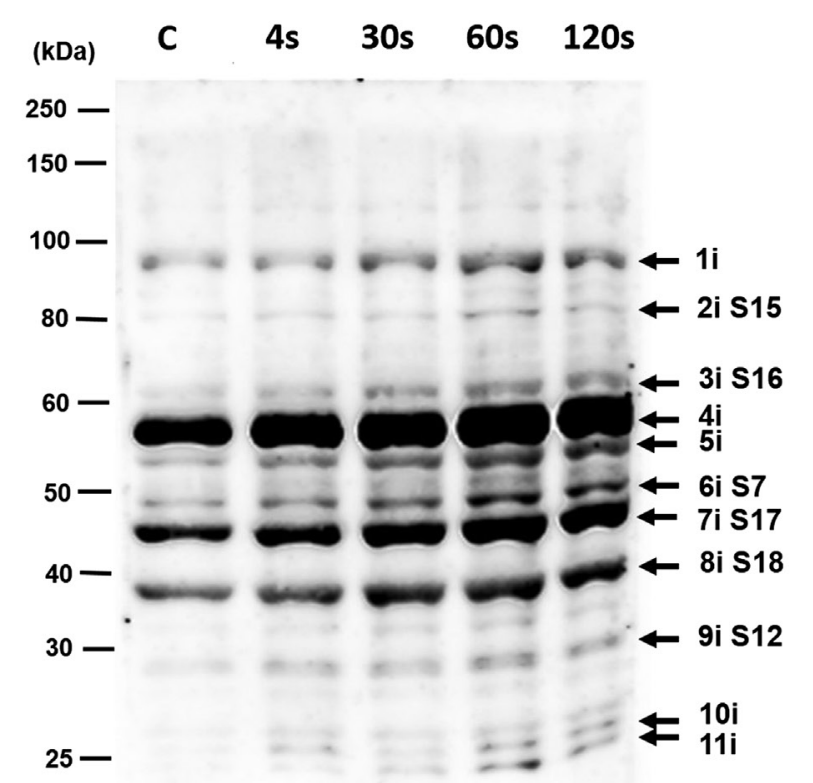

\begin{tabular}{|c|c|c|c|c|c|}
\hline & $\mathrm{c}$ & $4 \mathrm{~s}$ & $30 \mathrm{~s}$ & $60 \mathrm{~s}$ & $120 \mathrm{~s}$ \\
\hline Band $1 \mathrm{i}$ & $0,6 \pm 0,32^{\mathrm{a}}$ & $0,6 \pm 0,17^{\mathrm{a}}$ & $1,2 \pm 0,13^{\mathrm{b}}$ & $2,1 \pm 0,2^{\mathrm{c}}$ & $1,1 \pm 0,12^{\mathrm{b}}$ \\
\hline Band $2 \mathrm{i}$ & $0,3 \pm 0,04^{\mathrm{a}}$ & $0,7 \pm 0,15^{\mathrm{b}}$ & $0,8 \pm 0,24^{\mathrm{b}}$ & $2,0 \pm 0,31^{\mathrm{c}}$ & $1,2 \pm 0,46^{\mathrm{b}}$ \\
\hline Band $3 \mathrm{i}$ & $0,4 \pm 0,17^{\mathrm{a}}$ & $0,8 \pm 0,2^{\mathrm{a}}$ & $1,4 \pm 0,27^{\mathrm{b}}$ & $2,0 \pm 0,07^{\mathrm{c}}$ & $2,2 \pm 0,14^{\mathrm{c}}$ \\
\hline Band $4 \mathrm{i}$ & $0,9 \pm 0,1^{\mathrm{a}}$ & $1,3 \pm 0,03^{\mathrm{a}}$ & $1,5 \pm 0,15^{\mathrm{a}}$ & $2,8 \pm 0,18^{\mathrm{b}}$ & $2,9 \pm 0,6^{\mathrm{b}}$ \\
\hline Band $5 \mathrm{i}$ & $0,4 \pm 0,11^{\mathrm{a}}$ & $1,0 \pm 0,17^{\mathrm{b}}$ & $1,7 \pm 0,23^{\mathrm{b}}$ & $2,3 \pm 0,51^{\mathrm{c}}$ & $2,1 \pm 0,3^{\mathrm{c}}$ \\
\hline Band 6i & $0,4 \pm 0,09^{\mathrm{a}}$ & $0,9 \pm 0,08^{\mathrm{b}}$ & $1,3 \pm 0,3^{\mathrm{b}}$ & $2,6 \pm 0,25^{\mathrm{c}}$ & $2,3 \pm 0,34^{\mathrm{c}}$ \\
\hline Band 7i & $0,8 \pm 0,74^{\mathrm{a}}$ & $1,2 \pm 0,37^{\mathrm{a}}$ & $2,6 \pm 0,29^{\mathrm{b}}$ & $2,9 \pm 0,15^{\mathrm{b}}$ & $3,0 \pm 0,48^{\mathrm{b}}$ \\
\hline Band $8 \mathrm{i}$ & $0,7 \pm 0,16^{\mathrm{a}}$ & $1,0 \pm 0,38^{\mathrm{a}}$ & $1,8 \pm 0,42^{\mathrm{b}}$ & $2,5 \pm 0,55^{\mathrm{b}}$ & $1,9 \pm 0,15^{\mathrm{b}}$ \\
\hline Band 9i & $0,3 \pm 0,05^{\mathrm{a}}$ & $0,6 \pm 0,07^{\mathrm{b}}$ & $0,6 \pm 0,13^{\mathrm{b}}$ & $1,2 \pm 0,18^{\mathrm{c}}$ & $1,2 \pm 0,12^{\mathrm{c}}$ \\
\hline Band 10i & $0,2 \pm 0,1^{\mathrm{a}}$ & $0,7 \pm 0,09^{\mathrm{b}}$ & $0,6 \pm 0,25^{\mathrm{b}}$ & $1,1 \pm 0,2^{\mathrm{c}}$ & $1,5 \pm 0,09^{\mathrm{c}}$ \\
\hline Band 11i & $0,1 \pm 0,08^{\mathrm{a}}$ & $0,4 \pm 0,13^{\mathrm{b}}$ & $0,5 \pm 0,05^{\mathrm{b}}$ & $1,5 \pm 0,41^{\mathrm{c}}$ & $1,2 \pm 0,06^{\mathrm{c}}$ \\
\hline
\end{tabular}

C

Sterlet

Immotile spermatozoa Motile spermatozoa, 60s

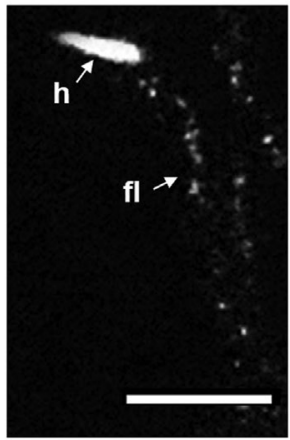

B

\section{Carp}

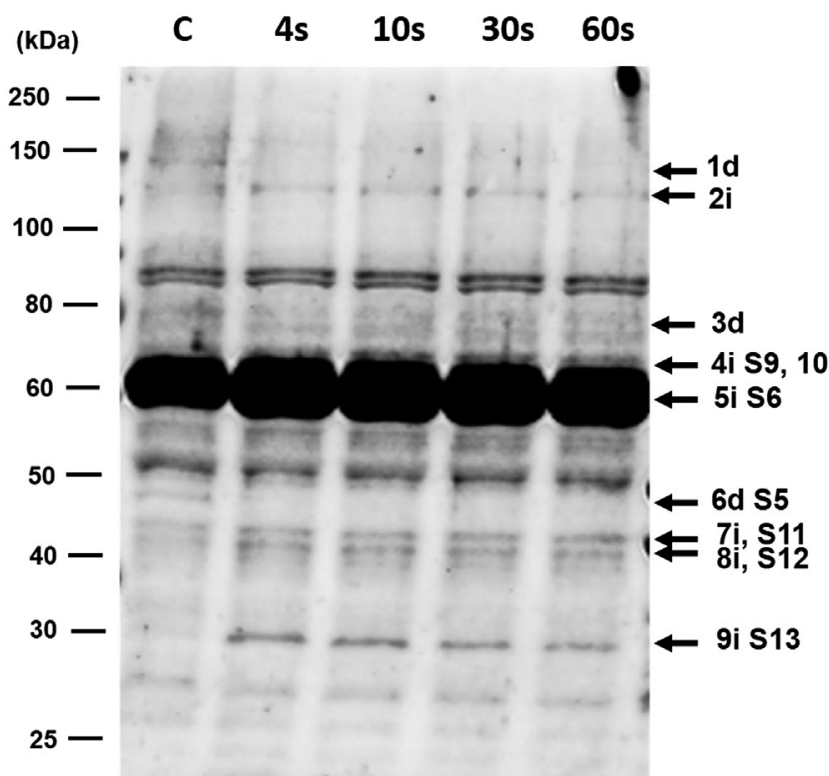

$10 \mathrm{i}$ S7, 8

\begin{tabular}{|c|c|c|c|c|c|}
\hline & $\mathrm{C}$ & $4 \mathrm{~s}$ & $10 \mathrm{~s}$ & $30 \mathrm{~s}$ & $60 \mathrm{~s}$ \\
\hline Band 1d & $0,8 \pm 0,05^{\mathrm{a}}$ & $0,2 \pm 0,0^{\mathrm{b}}$ & $0,3 \pm 0,13^{\mathrm{b}}$ & $0,3 \pm 0,08^{\mathrm{b}}$ & $0,3 \pm 0,04^{\mathrm{b}}$ \\
\hline Band 2i & $0,3 \pm 0,11^{\mathrm{a}}$ & $0,8 \pm 0,12^{\mathrm{b}}$ & $0,8 \pm 0,05^{\mathrm{b}}$ & $0,8 \pm 0,08^{\mathrm{b}}$ & $0,7 \pm 0,16^{\mathrm{b}}$ \\
\hline Band 3d & $0,9 \pm 0,0 \mathrm{a}$ & $0,6 \pm 0,1 \mathrm{a}^{\mathrm{a}}$ & $0,7 \pm 0,08^{\mathrm{a}}$ & $0,6 \pm 0,08^{\mathrm{a}}$ & $0,3 \pm 0,04^{\mathrm{b}}$ \\
\hline Band 4i & $0,5 \pm 0,06^{\mathrm{a}}$ & $0,6 \pm 0,1 \mathrm{a}^{\mathrm{a}}$ & $0,7 \pm 0,09^{\mathrm{a}}$ & $0,9 \pm 0,02^{\mathrm{b}}$ & $0,9 \pm 0,1^{\mathrm{b}}$ \\
\hline Band 5i & $1,8 \pm 0,07^{\mathrm{a}}$ & $2,3 \pm 0,25^{\mathrm{b}}$ & $2,1 \pm 0,38^{\mathrm{b}}$ & $2,1 \pm 0,34^{\mathrm{b}}$ & $2,2 \pm 0,15^{\mathrm{b}}$ \\
\hline Band 6d & $0,9 \pm 0,03^{\mathrm{a}}$ & $0,2 \pm 0,02^{\mathrm{b}}$ & $0,4 \pm 0,1^{\mathrm{b}}$ & $0,4 \pm 0,16^{\mathrm{b}}$ & $0,5 \pm 0,09^{\mathrm{b}}$ \\
\hline Band 7i & $0,6 \pm 0,01^{\mathrm{a}}$ & $0,9 \pm 0,04^{\mathrm{b}}$ & $0,9 \pm 0,03^{\mathrm{b}}$ & $0,9 \pm 0,06^{\mathrm{b}}$ & $0,8 \pm 0,06^{\mathrm{b}}$ \\
\hline Band 8i & $0,5 \pm 0,07^{\mathrm{a}}$ & $1,1 \pm 0,14^{\mathrm{b}}$ & $1,0 \pm 0,09^{\mathrm{b}}$ & $0,8 \pm 0,05^{\mathrm{b}}$ & $0,8 \pm 0,04^{\mathrm{b}}$ \\
\hline Band 9i & $0,2 \pm 0,04^{\mathrm{a}}$ & $1,2 \pm 0,07 \mathrm{c}$ & $1,0 \pm 0,16^{\mathrm{c}}$ & $0,8 \pm 0,14^{\mathrm{b}}$ & $0,7 \pm 0,02^{\mathrm{b}}$ \\
\hline Band 10i & $0,1 \pm 0,09^{\mathrm{a}} \mathrm{a}$ & $1,6 \pm 0,12^{\mathrm{b}}$ & $1,7 \pm 0,28^{\mathrm{b}}$ & $1,5 \pm 0,23^{\mathrm{b}}$ & $1,4 \pm 0,1^{\mathrm{b}}$ \\
\hline
\end{tabular}

D

\section{Carp}

Immotile spermatozoa

Motile spermatozoa, 60s

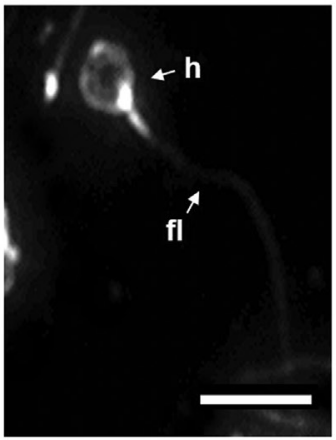

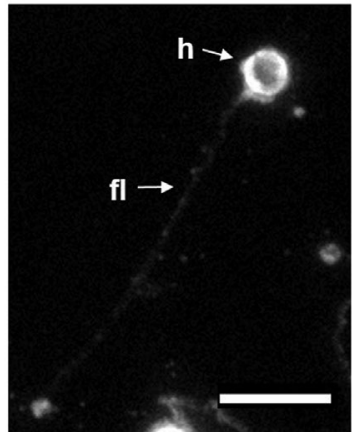

Figure 4 Reaction of anti-phosphoserine antibody with spermatozoa from sterlet (A and C) or carp (B and D). (A and B) Western blots on proteins extracted from spermatozoa either in immobilizing medium (control, C) or at different times (in seconds) after motility activation. Arrows on the right indicate protein bands that changed phosphorylation state after motility activation: $\mathrm{i}=$ increased phosphorylation, $\mathrm{d}=$ decreased phosphorylation. S numbers correspond to spots which were identified by mass spectrometry and are listed in Table 2 (sterlet) or Table 3 (carp). Molecular weight markers $(\mathrm{kDa})$ are on the left. Relative intensities of phosphorylated bands are summarized in tables below the Western blot images. Values are expressed as means \pm S.E. $(n=3)$. Small letters $(a, b, c)$ indicate significant differences within a row (Kruskal-Wallis test, $P<0.05$ ). (C and D) Immunolocalization of proteins phosphorylated on serine residue in immotile and activated spermatozoa which were attached to glass slides and fixed: $\mathrm{h}=$ head of spermatozoon, $\mathrm{fl}=$ flagella. Bars represent approximately $10 \mu \mathrm{m}$. 
A

(kDa)
Sterlet

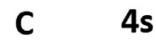

30s

60s

120s

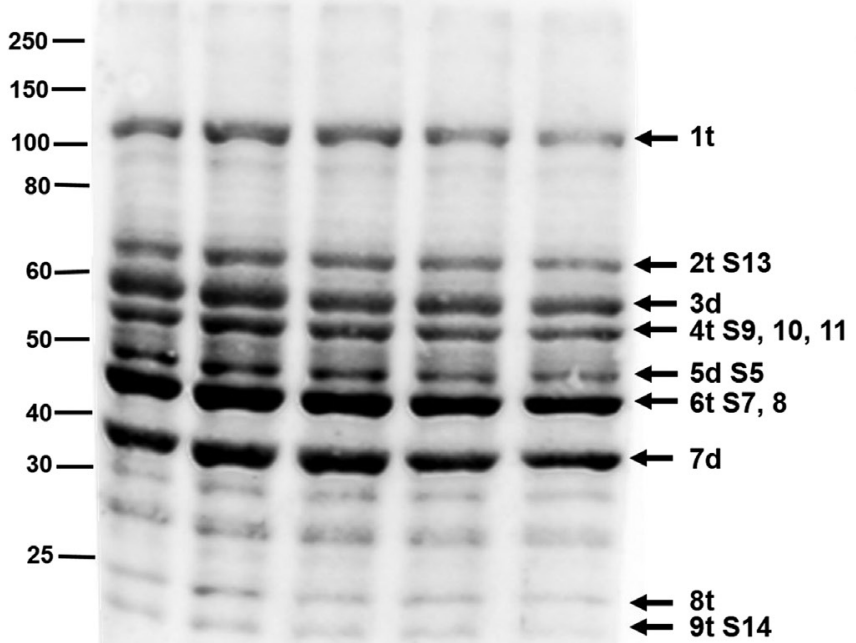

B

Carp

(kDa) $\quad \mathrm{C} \quad 4 s \quad 10 \mathrm{~s}$ 30s 60s

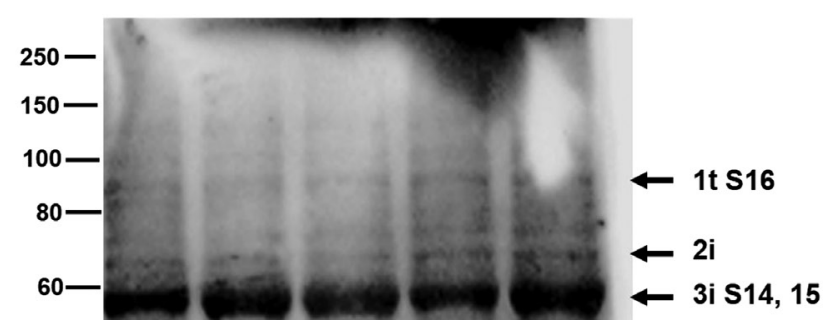

$\leftarrow 4 \mathrm{i} 33$

$5 i \mathrm{~S} 12$

\begin{tabular}{|c|c|c|c|c|c|}
\hline & $\mathrm{C}$ & $4 \mathrm{~s}$ & $10 \mathrm{~s}$ & $30 \mathrm{~s}$ & $60 \mathrm{~s}$ \\
\hline Band $1 \mathrm{t}$ & $0,8 \pm 0,12^{\mathrm{a}}$ & $0,6 \pm 0,24^{\mathrm{a}}$ & $0,3 \pm 0,16^{\mathrm{b}}$ & $0,9 \pm 0,15^{\mathrm{a}}$ & $1,0 \pm 0,22^{\mathrm{b}}$ \\
\hline Band $2 \mathrm{i}$ & $1,0 \pm 0,05^{\mathrm{a}}$ & $0,6 \pm 0,07^{\mathrm{b}}$ & $0,5 \pm 0,13^{\mathrm{b}}$ & $1,0 \pm 0,18^{\mathrm{a}}$ & $1,5 \pm 0,05^{\mathrm{c}}$ \\
\hline Band $3 \mathrm{i}$ & $1,6 \pm 0,22^{\mathrm{a}}$ & $1,5 \pm 0,19^{\mathrm{a}}$ & $1,1 \pm 0,1^{\mathrm{b}}$ & $1,1 \pm 0,06^{\mathrm{b}}$ & $2,3 \pm 0,15^{\mathrm{c}}$ \\
\hline Band $4 \mathrm{i}$ & $1,0 \pm 0,06^{\mathrm{a}}$ & $0,8 \pm 0,13^{\mathrm{a}}$ & $0,5 \pm 0,13^{\mathrm{b}}$ & $0,8 \pm 0,17^{\mathrm{a}}$ & $1,5 \pm 0,14^{\mathrm{c}}$ \\
\hline Band $5 \mathrm{i}$ & $0,7 \pm 0,06^{\mathrm{a}}$ & $0,5 \pm 0,05^{\mathrm{a}}$ & $0,4 \pm 0,02^{\mathrm{b}}$ & $0,6 \pm 0,02^{\mathrm{a}}$ & $1,6 \pm 0,1^{\mathrm{c}}$ \\
\hline Band $6 \mathrm{t}$ & $0,4 \pm 0,06^{\mathrm{a}}$ & $0,9 \pm 0,03^{\mathrm{b}}$ & $0,8 \pm 0,07^{\mathrm{b}}$ & $0,4 \pm 0,06^{\mathrm{a}}$ & $0,8 \pm 0,08^{\mathrm{b}}$ \\
\hline
\end{tabular}

D

Carp

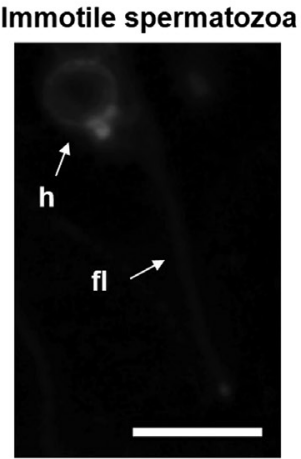

Motile spermatozoa, $60 \mathrm{~s}$

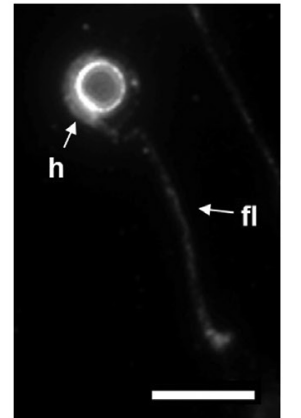

Figure 5 Reaction of anti-phosphotyrosine antibody with spermatozoa from sterlet ( $A$ and C) or carp (B and D). (A and B) Western blots on proteins extracted from spermatozoa either in immobilizing medium (control, C) or at different times (in seconds) after motility activation. Arrows on the right indicate protein bands that changed phosphorylation state after motility activation: $\mathrm{i}=$ increased phosphorylation, $\mathrm{d}$ = decreased phosphorylation, $\mathrm{t}=$ temporarily modified band. $\mathrm{S}$ numbers correspond to spots which were identified by mass spectrometry and are listed in Table 2 (sterlet) or Table 3 (carp). Molecular weight markers (kDa) are on the left. Relative intensities of phosphorylated bands are summarized in tables below the Western blot images. Values are expressed as means \pm S.E. $(n=3)$. Small letters $(\mathrm{a}, \mathrm{b}, \mathrm{c})$ indicate significant differences within a row (Kruskal-Wallis test, $P<0.05$ ). (C and D) Immunolocalization of proteins phosphorylated on tyrosine residue in immotile and activated spermatozoa which were attached to glass slides and fixed: $\mathrm{h}=$ head of spermatozoon, $\mathrm{fl}=\mathrm{flagella}$. Bars represent approximately $10 \mu \mathrm{m}$. 
A

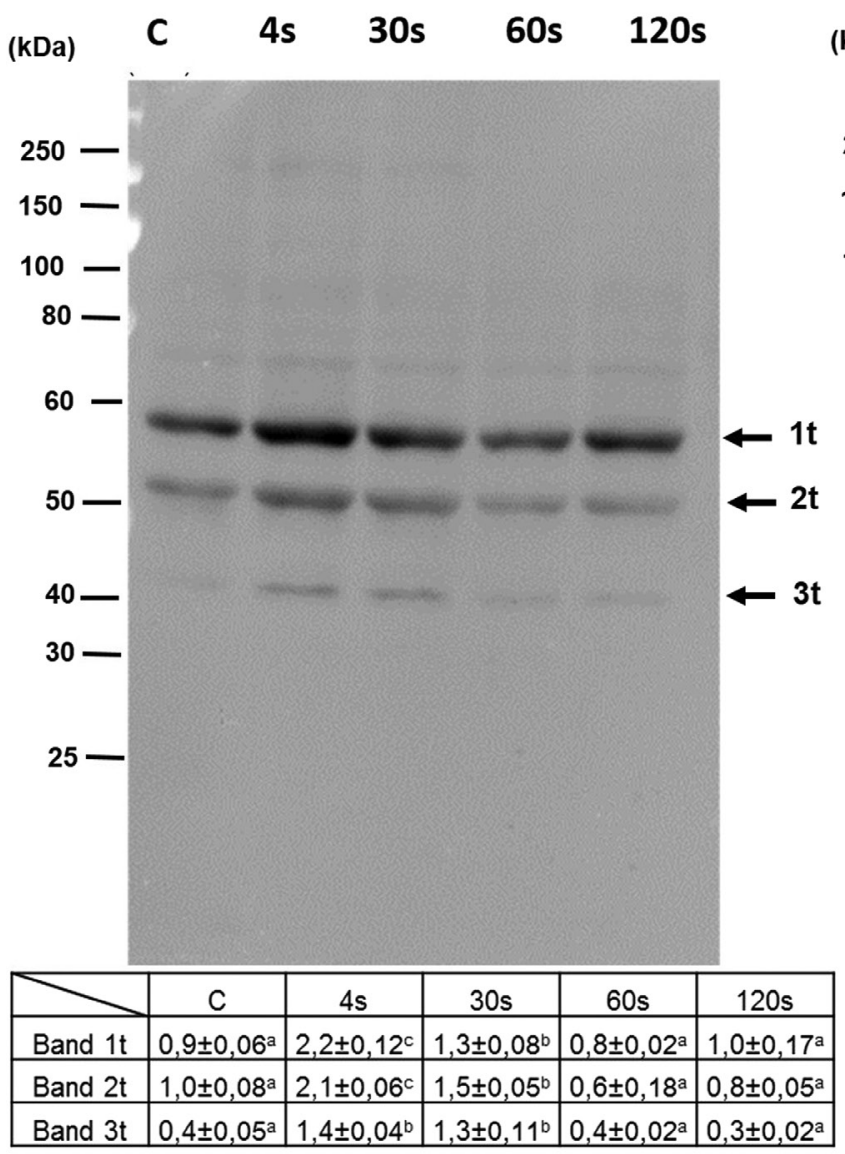

B

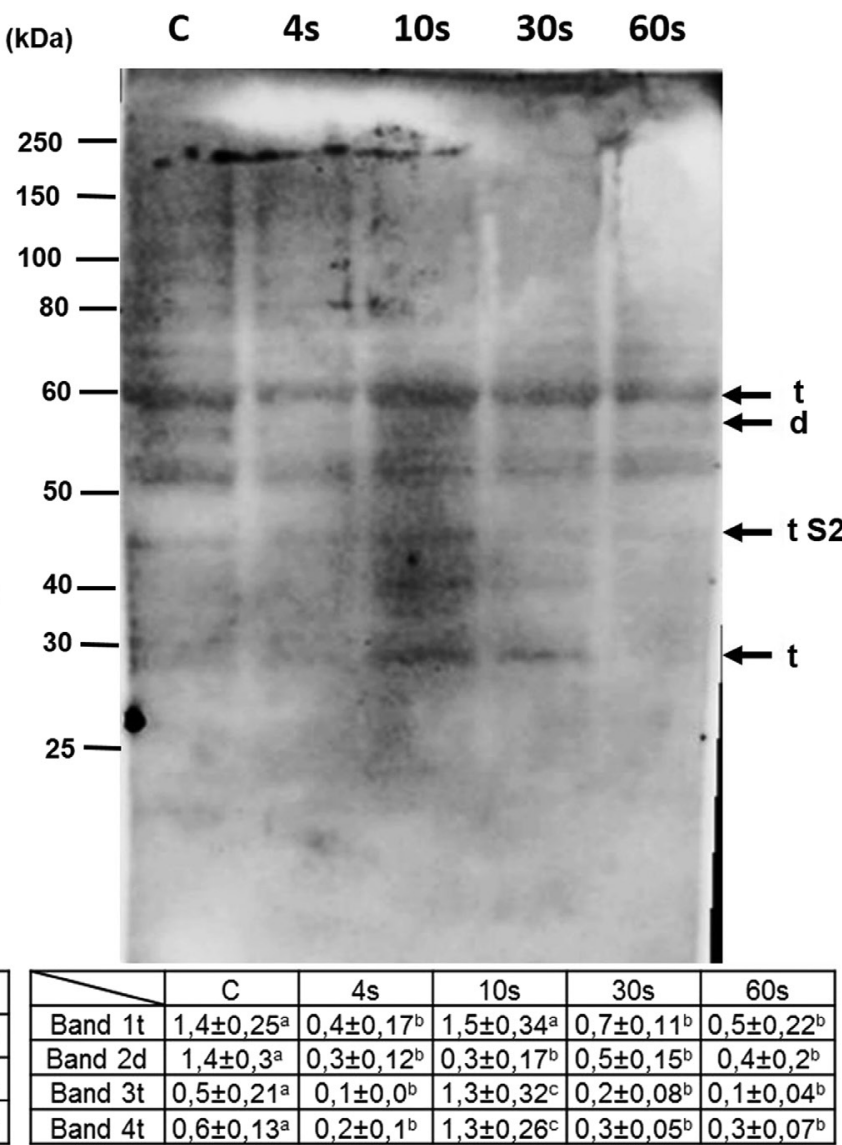

C Immotile spermatozoa

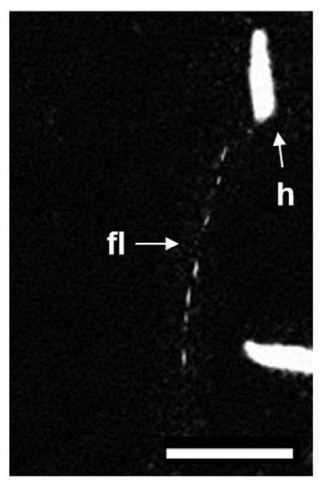

Sterlet

Motile spermatozoa, 60s

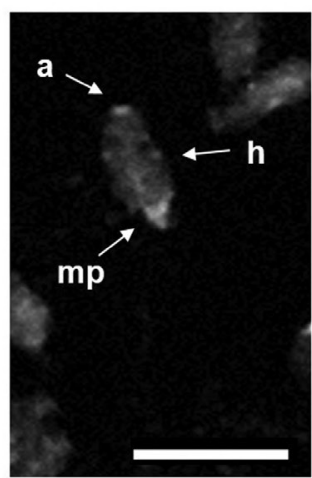

Carp

Immotile spermatozoa

Motile spermatozoa, 60s

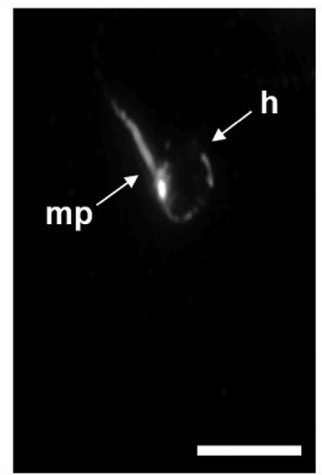

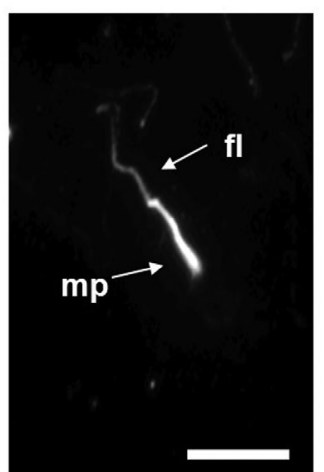

Figure 6 Reaction of anti-phosphothreonine antibody with spermatozoa from sterlet (A and C) or carp (B and D). (A and B) Western blots on proteins extracted from spermatozoa either in immobilizing medium (control, C) or at different times (in seconds) after motility activation. Arrows on the right indicate protein bands that changed phosphorylation state after motility activation: $\mathrm{d}=$ decreased phosphorylation, $\mathrm{t}=$ temporarily modified band. $\mathrm{S}$ numbers correspond to spots which were identified by mass spectrometry and are listed in Table 2 (sterlet) or Table 3 (carp). Molecular weight markers $(\mathrm{kDa})$ are on the left. Relative intensities of phosphorylated bands are summarized in tables below the Western blot images. Values are expressed as means \pm S.E. $(n=3)$. Small letters $(\mathrm{a}, \mathrm{b}, \mathrm{c})$ indicate significant differences within a row (Kruskal-Wallis test, $P<0.05$ ). (C and D) Immunolocalization of proteins phosphorylated on threonine residue in immotile and activated spermatozoa which were attached to glass slides and fixed: $\mathrm{h}=$ head of spermatozoon, $\mathrm{fl}=$ flagella, $\mathrm{mp}=$ midpiece. Bars represent approximately $10 \mu \mathrm{m}$. 
to phosphorylation of PKA substrates in spermatozoa of carp and sterlet (Fig. 3A and B). This fact indicates higher sensitivity of phospho-PKA substrate antibodies compared to less specific antibodies to phosphorylated residues, as has been recently reported for reptile spermatozoa (Nixon et al. 2016).

Incubation with anti-phosphothreonine antibodies revealed a weak phosphorylation of flagella in sterlet spermatozoa. Most phosphorylated proteins were localized in the head of immotile spermatozoa and in the midpiece of motile spermatozoa (Fig. 6C). In carp, phosphorylation on threonine residue occurred mainly in the head and midpiece of immotile spermatozoa and translocated to the principal part of flagella after motility activation. (Fig. 6D).

\section{Identification of proteins whose phosphorylation state is modified following motility activation}

To identify phospho-proteins involved in spermatozoa motility, proteins extracted from spermatozoa before and after motility activation were separated with 2DE, blotted on PVDF membrane and incubated with antibodies to either phospho-(Ser/Thr) PKA substrate, phospho-(Ser) PKC substrate, phosphoserine, phosphotyrosine or phosphothreonine (Supplementary Fig. 2A, B, C, D and $\mathrm{E}$, respectively). Figure 7 represents total protein profiles (Coomassie Brilliant Blue R-250 stain) of sterlet and carp spermatozoa before and after motility activation (at $30 \mathrm{~s}$ post activation for carp sperm and $120 \mathrm{~s}$ for sterlet). Spots 1-5 in sterlet spermatozoa and spots $1-4$ in carp spermatozoa were identified as phospho-(Ser/Thr) PKA substrates, phosphorylated or dephosphorylated after motility activation (Supplementary Fig. 2A). Spot 6 in sterlet spermatozoa was found to be a phospho-(Ser) PKC substrate, slightly dephosphorylated after motility activation (Supplementary Fig. 2B). Incubation with anti-phosphoserine antibodies revealed an increased phosphorylation of spots $7,12,15-18$ in sterlet spermatozoa and of spots 7-13 in carp after motility activation (Supplementary Fig. 2C). Spot 5 in carp spermatozoa was dephosphorylated on serine residue after motility activation. Spots 5, 7-9, 11, 13 and 14 in sterlet spermatozoa were dephosphorylated on tyrosine residue after motility activation, whereas spots 10 and 12 in sterlet sperm and spots 3,12, 14-16 in carp were phosphorylated on tyrosine during motility period (Supplementary Fig. 2D). Protein phosphorylation on threonine residue was weak in spermatozoa of both species. Only spot 2 in carp sperm was identified with anti-phosphothreonine antibody (Supplementary Fig. 2E).

Proteins of interest were cut from 2D gels (Fig. 7) and analyzed with MALDI-TOF MS/MS. We were able to identify 18 of 38 selected protein spots in sterlet spermatozoa and 16 of 30 spots in carp. A detailed list of these sterlet and carp spermatozoa proteins phosphorylated during sperm motility is provided in Tables 2 and 3, respectively, together with their accession number, molecular mass, sequence coverage, number of unique peptides, phosphorylated amino acid residue and the main biological function. The majority
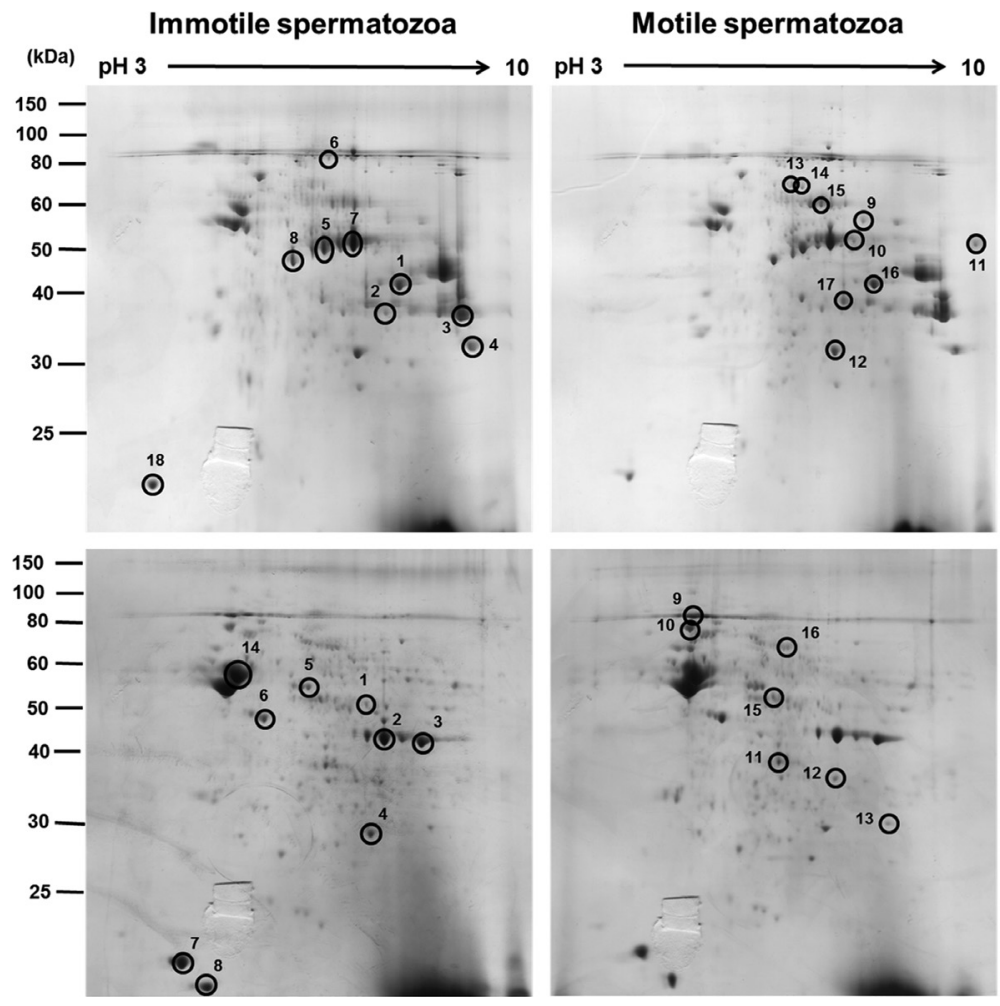

\section{Sterlet}

Carp
Figure 7 Two-dimensional gel electrophoresis of sterlet and carp spermatozoa proteins. The separated proteins were stained with Coomassie Brilliant Blue R-250. Labeled spots correspond to proteins phosphorylated or dephosphorylated after motility activation, as determined by immunoblots (see Supplementary files). 


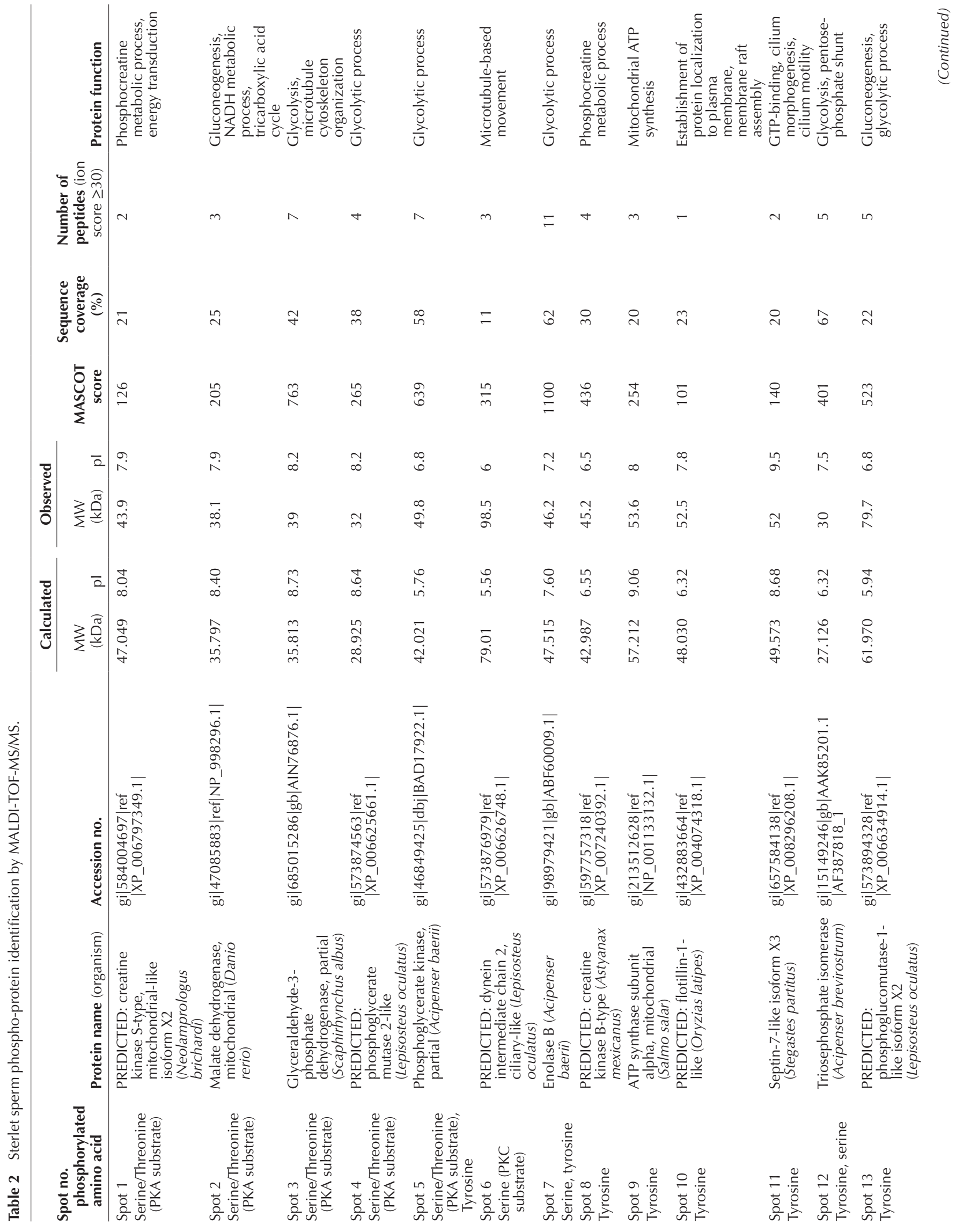




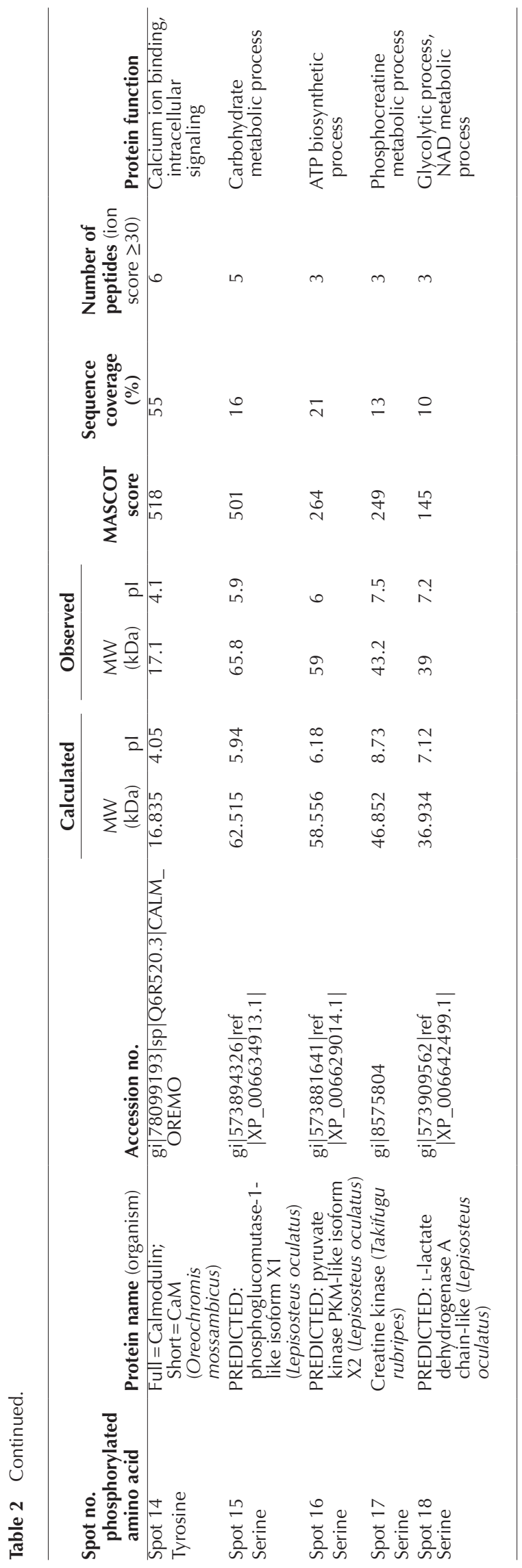

of identified proteins (14/18 for sterlet and 8/16 for carp) are involved in energy production, via oxidative phosphorylation or the glycolytic pathway. Among the others were cytoskeletal components, heat shock proteins and calcium-regulating enzymes. We discuss below each of these findings and their potential meaning for fish sperm motility.

\section{Discussion}

After spawning into an aqueous medium, fish spermatozoa exhibit dramatic changes, from initiation of motility to acrosome reaction in some species. These changes are triggered by changes in the extracellular ionic environment and osmolality. After reception of extracellular signals by specific ion channels or receptors in the spermatozoon, intracellular signals are transferred to the sperm axoneme through protein phosphorylation, $\mathrm{Ca} 2+$ signaling and cAMP-dependent pathways (Inaba 2003). For the two evolutionarily distant fish species, common carp (Cyprinus carpio L.) and sturgeon (Acipenser ruthenus), not only does the trigger of motility activation differ (Bondarenko et al. 2013), but the intracellular signaling pathways vary as well. Therefore, the present study was undertaken in order to clarify which phospho-proteins and protein kinases are involved in sperm motility and intracellular signaling in these two important aquaculture species.

\section{Involvement of PKA and PKC in sperm motility}

Results of motility analyses in the presence of kinase inhibitors showed that PKC participates in motility activation in both species, while PKA seems to be involved in motility only for carp spermatozoa. It should be mentioned that the specificity of inhibitors is never perfect, and that various isoforms of each kinase may be expressed (White et al. 2007). For example, even though in the present study an inhibitor of protein tyrosine kinase (tyrphostin 23) did not show any significant effect on spermatozoa motility (Table 1), tyrosine phosphorylation of numerous sperm proteins was observed (Fig. 5 and Supplementary Fig. 2), indicating that they may be involved in initiating or regulating spermatozoa motility. Furthermore, chelerythrine, the inhibitor of PKC, has been shown to inhibit only lipid-stimulated and not basal kinase activity (Herbert et al. 1990). Thus, it can be speculated that the specificity of this inhibitor is lower compared to Go 6983 that, however, had no effect on fish sperm motility. Taking these facts into account, we suggest that further studies with a series of inhibitors are needed to evaluate the role of each kinase in fish spermatozoa motility.

Numerous studies have described the role of PKA in sperm motility of different species (Visconti et al. 1995, Inaba 2003, Lasko et al. 2012, Nixon et al. 2016). It is generally assumed that the activity of PKA depends on 


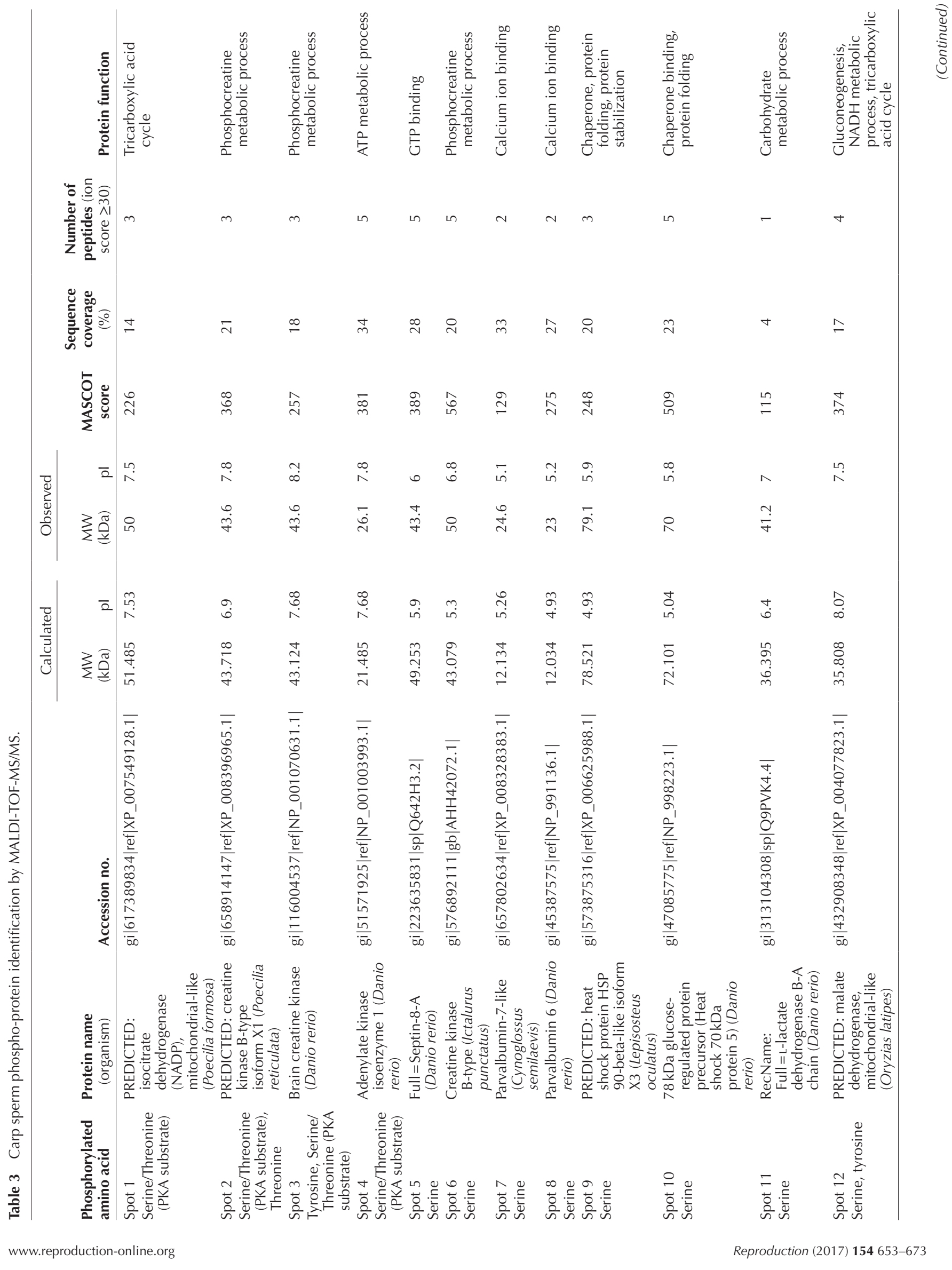




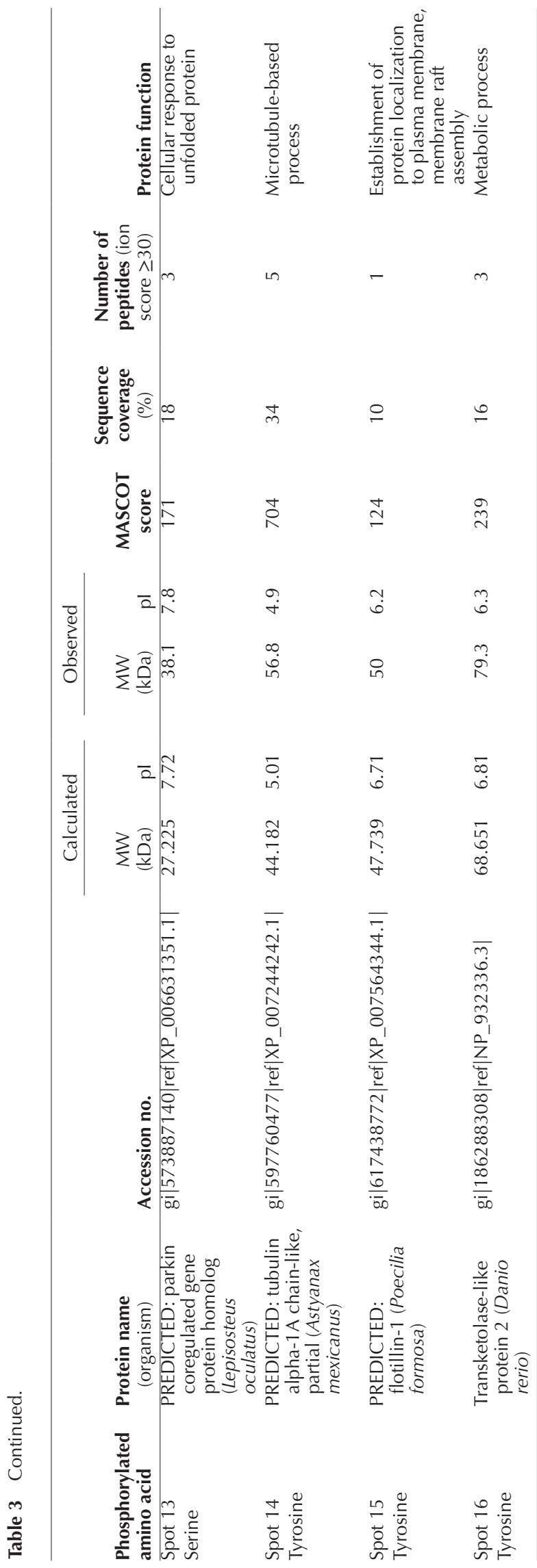

the concentration of cAMP, which is in turn regulated by adenylate cyclase and phosphodiesterase. The binding of CAMP to PKA regulatory subunits promotes the dissociation of the active catalytic subunits, which can then phosphorylate target proteins on serine/threonine residues (Urner \& Sakkas 2003). Involvement of PKA in fish spermatozoa motility was shown only for salmonids (Itoh et al. 2003), though cAMP-dependent regulation pathways were also reported in spermatozoa of Sparus aurata (Zilli et al. 2008) and Polyodon spathula (Linhart et al. 2002). In the current study, we show both by Western blotting and immunolabeling that sterlet and carp spermatozoa harbor PKA and that proteins are phosphorylated by PKA differently before and after sperm motility activation. Moreover, the phosphorylation patterns differ between sterlet and carp over time after activation, with a global rise in phosphorylation for sterlet protein extract compared to a decrease of global phosphorylation in carp extracts (Fig. $3 \mathrm{~A}$ and $\mathrm{B}$ ). This may reflect a species difference in the requirement of cAMP-activated kinase for motility activation vs motility maintenance. We found that 4 proteins $(125,49,30$ and $27 \mathrm{kDa})$ were transiently phosphorylated between 4 and $30 \mathrm{~s}$ following sperm activation in carp. Two of these proteins were identified as isocitrate dehydrogenase (NADP), mitochondrial-like $(51 \mathrm{kDa})$ and adenylate kinase isoenzyme 1 (20 kDa) involved in energy production pathways (Table 3 ). It is known that the activation of motility does not depend on cAMP in carp (Cosson \& Gagnon 1988, Krasznai et al. 2000); therefore, these proteins are probably involved in the phase of motility maintenance. This result is in agreement with the recently published study of Dzyuba and coworkers that reported adenylate kinase activity in motile spermatozoa of carp and sterlet (Dzyuba et al. 2016).

Localization of PKA and PKA substrates and results of protein identification in carp spermatozoa (Figs 1D and 3D) supports the hypothesis that PKA is involved in energy production and motility maintenance. Thus, results of immunolabeling of carp spermatozoa showed only weak phosphorylation of PKA substrates in the midpiece of immotile spermatozoa, which was followed by increased phosphorylation of the midpiece and flagella after motility activation. It can be suggested that in quiescent carp spermatozoa, PKA is anchored in the midpiece and shows low activity in mitochondria; however, after motility activation, activity of PKA increases in both mitochondria and cytosol. These results correlate with the results of protein identification by mass spectrometry, which showed that in carp spermatozoa, PKA substrates phosphorylated after motility activation include mitochondrial protein isocitrate dehydrogenase (NADP) and cytoplasmic proteins creatine kinase and adenylate kinase (Table 3). All these enzymes are involved in ATP metabolism and play important roles in cellular energy homeostasis. 
In sterlet, results of Western blotting and immunolabeling seem to indicate involvement of PKA in sperm motility. That was expected, since sturgeon spermatozoa motility activation is cAMP dependent (Linhart et al. 2002). However, in sterlet, the PKA inhibitor $\mathrm{H}-89$ had only a slight effect on sperm motility at a concentration far above that recommended for specificity. Incubation with $\mathrm{H}-89$ led to a decrease in PKA substrate phosphorylation in both carp and sterlet spermatozoa, indicating specificity of the inhibitor. Thus, observed phosphorylation of PKA substrates in sterlet spermatozoa seems to be involved in maintenance of motility rather than in its activation.

In both quiescent and motile sterlet spermatozoa, PKA and PKA substrates were localized in the head and flagella (Figs 1D and 3C). The PKA substrates we identified were mitochondrial proteins: creatine kinase S-type and malate dehydrogenase and cytoplasmic proteins: phosphoglycerate kinase, glyceraldehyde3-phosphate dehydrogenase and phosphoglycerate mutase. These results suggest that in fish spermatozoa, PKA is involved not only in phosphorylation of axonemal proteins as shown before (Itoh et al. 2003), but also plays an important role in oxidative phosphorylation and the glycolytic pathway. Several studies have previously described the role of PKA in mitochondria function in muscle and liver (Lark et al. 2015), and in bovine spermatozoa (Mizrahi \& Breitbart 2014). Hence, it is possible to speculate that PKA activity regulates ATP generation and/or transport along the flagella in order to sustain spermatozoa motility in carp and sterlet.

PKC has been shown to transduce signals during initiation and maintenance of motility in intact sea urchin spermatozoa (White et al. 2007) and in glycerol-treated salmonid sperm (Takei et al. 2012). Previous studies reported the involvement of PKC in the acrosome reaction and gamete fusion (reviewed by Breitbart \& Naor 1999); however, less is known about the function of PKC in sperm motility activation. In the current study, motility was blocked in the presence of the PKC inhibitor (chelerythrine) both in C. carpio and A. ruthenus spermatozoa, and results of Western blotting and immunolabeling indicated the presence of PKC and phosphorylated PKC substrates in spermatozoa of both species. Though we were not able to identify PKC substrates in carp spermatozoa due to low signal from antibodies on immunoblots of 2D gels, the involvement of protein kinase $C$ and casein kinase substrate protein in carp sperm motility has been recently reported (Dietrich et al. 2016). Thus, our results indicate that this protein is temporarily phosphorylated during motility period. The PKC substrate in sterlet spermatozoa was identified as dynein intermediate chain 2 (IC2). This protein was phosphorylated in immotile spermatozoa and its dephosphorylation in the presence of chelerythrine correlated with a blocking of motility activation. Therefore, it can be suggested that IC2 in a phosphorylated state is required for sperm movement. Our results are in agreement with a previous study that showed that in sea urchin spermatozoa, the majority of the phospho-PKC substrate proteins, and PKC itself, were associated with the flagellum and axoneme (White et al. 2007). Similarly, in human spermatozoa, PKC was shown to localize in the head and in patches along the flagella, and to participate in sperm motility activation (Kalina et al. 1995).

The crosstalk between two kinases, PKA and PKC, has been reported for mammalian spermatozoa (Cohen et al. 2004). It has been shown that activation of PKA leads to the inhibition of phospholipase C (PLC) and prevents PKC activation during capacitation. Inhibition of PLC also has been shown to block trout sperm motility, possibly through modulation of $\mathrm{Ca} 2+$ signaling (Takei et al. 2012). Though no information on interaction between PKA, PKC and PLC is available for fish spermatozoa, results of our study permit speculation that a similar mechanism may be functioning in fish sperm. Thus, in sterlet spermatozoa, the gradual increase in PKA substrate phosphorylation during motility period was accompanied by a slow decrease in PKC substrate phosphorylation (Figs 2A and 3A). In carp spermatozoa, transient phosphorylation of PKA substrates at $4 \mathrm{~s}$ after motility activation correlates with transient dephosphorylation of PKC substrates at the same time point (Figs $2 \mathrm{~B}$ and $3 \mathrm{~B}$ ). Thus, it is worth investigating in future studies the possible interaction between PKA and $\mathrm{PKC}$, as well as the role of phospholipase cascade in fish sperm motility.

\section{Identified phospho-proteins involved in sperm motility}

We observed that many proteins changed their phosphorylation status after motility activation (Figs 4, 5 and 6). Unfortunately, we were not able to identify all phospho-proteins in carp and sterlet spermatozoa due to the absence of protein databases and incomplete genome sequencing. Nevertheless, we identified 6 serine-phosphorylated proteins involved in sterlet spermatozoa motility: phosphoglucomutase-1-like, pyruvate kinase PKM-like, creatine kinase, L-lactate dehydrogenase A chain, triose phosphate isomerase, enolase B. All these enzymes participate in the glycolytic pathway and regulate energy production. Results of immuno-fluorescence labeling indicate that phosphoserine proteins are localized in the head and along the flagellum of sterlet spermatozoon. Increased intensity of fluorescence after motility activation (Fig. 4C) correlates with results of Western blotting and may reflect the activation of glycolytic processes. The abundance of metabolic enzymes participating in sterlet sperm motility may explain the relatively long period of their movement (up to $3 \mathrm{~min}$ ), compared to other freshwater fish species (60s in carp), as well as the slow 
ATP decrease in sterlet spermatozoa during the motility period (Billard et al. 1999, Dzyuba et al. 2016).

For comparison, among the 9 serine-phosphorylated carp sperm proteins we identified, only 3 proteins belong to energy metabolic pathways (creatine kinase B-type, L-lactate dehydrogenase B-A chain, and malate dehydrogenase). The rest of the serine phospho-proteins are axonemal (septin-8-A, parkin coregulated gene protein homolog), calcium-binding (parvalbumin-7like, parvalbumin 6) or heat shock (Hsp90 and Hsp70) proteins. Thus, compared to sterlet spermatozoa, in carp only a few proteins are involved in energy production during motility period. Therefore, it can be suggested that carp spermatozoa motility mostly depend on ATP produced and stored prior to motility activation.

In both species of fish, some of the tyrosinephosphorylated proteins belong to ATP production and energy homeostasis pathways as well: malate dehydrogenase, transketolase, adenylate kinase and creatine kinase in carp spermatozoa; enolase B, phosphoglycerate kinase, creatine kinase B-type, ATP synthase subunit alpha, triosephosphate isomerase and phosphoglucomutase-1-like isoform X2 in sterlet spermatozoa. As was the case for serine phosphoproteins, the most abundant tyrosine phospho-proteins in sterlet spermatozoa were proteins associated with glycolysis and energy metabolism. Results of Western blotting indicate increased tyrosine phosphorylation right after motility activation and slow dephosphorylation of tyrosine residues in proteins up to the end of motility period, which correlates well with temporal requirements for energy production.

Our results suggest that in addition to mitochondria functions and glycolysis other signaling pathways are also regulated by protein phosphorylation. Thus, two heat shock proteins (HSPs) were phosphorylated after motility activation in carp spermatozoa. The role of HSPs in spermatozoa has been studied in mammals (Cole \& Meyers 2011) and ascidians (Satouh et al. 2005). HSPs are classified as chaperone proteins, which protect intracellular macromolecules against unfolding and aggregation. Heat shock protein 70 (Hsp70) and heat shock protein 90 (Hsp90) are present in the cytosol and nucleus of somatic cells; they refold and transport proteins and play an important role in the cellular distribution of proteins (Kakar et al. 2006). Previous studies also reported an increase in the phosphorylation of HSP70 under osmotic stress (Cole \& Meyers 2011), and of HSP90 during human sperm capacitation (Li et al. 2014). HSP70 was shown to localize in the head and HSP90 in the midpiece of monkey spermatozoa (Cole \& Meyers 2011). This corresponds to our immunolabeling results, which showed an increased phosphorylation on serine residues in the head and midpiece of carp spermatozoa after motility activation.

Our study revealed that calmodulin (CaM) is regulated by tyrosine phosphorylation in sterlet spermatozoa.
Involvement of CaM in sperm motility has been reported for many other aquatic species, such as tilapia (Morita et al. 2006) and ascidians (Nomura et al. 2004). $\mathrm{CaM}$ is considered to be a ubiquitous protein mediating intracellular $\mathrm{Ca} 2+$ signaling, which activates sperm motility through the activation of dynein ATPase (Tash et al. 1988). Hence, our results are in agreement with previous studies, which showed $\mathrm{Ca} 2+$ dependence of sturgeon sperm motility activation (Alavi et al. 2011). In spermatozoa of carp, we found serine phosphorylation on parvalbumin (PV), a calcium-binding protein with three EF-hand motifs, which is structurally related to CaM. A previous study reported the presence of PV and $\mathrm{CaM}$ in carp spermatozoa and their participation in sperm motility (Dietrich et al. 2016). Results of the current study indicate that activity of both proteins is controlled by phosphorylation. Interestingly, compared to other Ca2+-binding proteins, such as CaM, PV has a slow dissociation and association rate, due to the fact that $\mathrm{Mg} 2+$ ions compete with $\mathrm{Ca} 2+$ ions for binding (Caillard et al. 2000). Hence, it is possible that the presence of PV in carp spermatozoa allows a different Ca2+ signaling mechanism, compared to spermatozoa of species which mostly rely on CaM such as sterlet (Table 2) or tilapia (Morita et al. 2006). Further studies are needed to understand the role of PV in spermatozoa of common carp.

In a previous study, we found that septin-8-A is dephosphorylated during oxidative stress in carp spermatozoa (Gazo et al. 2015), and a similar result was obtained in the current study after sperm motility activation in hypotonic conditions (Supplementary Fig. 2). We also detected septin 7 as a protein phosphorylated on tyrosine in sterlet sperm. Septins are a highly conserved family of GTP-binding proteins that co-localize with cellular membranes and the microtubule cytoskeleton (Spiliotis 2010). Studies on mammals showed that septins are localized in the annulus - a fibrous structure between the midpiece and principal piece of the sperm tail. Also, partial co-localization with microtubules has been reported for septin 7 (Spiliotis 2010). The role of septins in fish sperm motility is not yet clear. However, it can be suggested that microtubule-associated septins may spatially modulate the association of tubulin with posttranslationally modifying enzymes and microtubule motors. This idea is supported by increased alphatubulin phosphorylation in carp spermatozoa (Fig. 5B, Supplementary Fig. 2, and Table 3), where septin-8-A was also dephosphorylated after motility activation. Immunofluorescent localization of phosphotyrosine in the current study indicates increased phosphorylation in flagella of carp spermatozoa after motility activation. This result is in agreement with tubulin localization shown by Tash and Means (1982) in dog sperm. The physiological relevance of alpha-tubulin phosphorylation in fish spermatozoa remains to be determined. 
Flotillin-1 was identified in spermatozoa of both species as being phosphorylated on tyrosine residue during motility period. Flotillin-1 is a membrane-associated protein, which is thought to function in a number of cellular contexts, including signaling, endocytosis and interactions with the cytoskeleton. It has been shown that capacitation of boar spermatozoa induced redistribution of flotillin-1 within the plasma membrane of the spermatozoon head (van Gestel et al. 2005). Moreover, tyrosine phosphorylation is known to control the distribution of flotillin microdomains (Riento et al. 2009), and sperm capacitation in different species (Aitken \& Nixon 2013, Nixon et al. 2016). In our study, tyrosine phosphorylation of the head membrane region of both carp and sterlet spermatozoa increased after motility initiation, which may be an indicator of the reorganization of lipid rafts after motility initiation. To our knowledge, this is the first evidence of capacitationlike processes in fish spermatozoa.

\section{Conclusion}

In conclusion, spermatozoa protein phosphorylation patterns differ significantly between two species, C. carpio L. and A. ruthenus. Differences in the way motility activation is triggered are followed by variations in intracellular signaling and implementation of secondary messengers. Though PKA and PKC are important participants in sperm motility, the roles of these two kinases seem to be different between the two species. Thus, PKA seems to play an important role in energy production and the sustaining of carp and sterlet spermatozoa motility. However, despite the fact that carp spermatozoa movement mainly depends on ATP stored before activation (Perchec et al. 1995), inhibition of PKA activity led to a significant reduction in percentage motile cells. On the other hand, sterlet spermatozoa movement was less sensitive to PKA inhibition. This could be due to the abundance of glycolytic enzymes in sterlet spermatozoa, which may indicate the presence of other, PKA-independent, pathways of ATP production.

Furthermore, the difference in phospho-(Ser) PKC substrate abundance between carp and sterlet spermatozoa, as well as the presence of PV instead of CaM in carp sperm, may reflect different types of involvement of $\mathrm{Ca} 2+$ signaling in sperm motility. Further studies are needed to understand the mechanisms of $\mathrm{Ca} 2+$ signaling during sperm motility activation in these two species.

An increased intensity of serine and tyrosine phosphorylation in the head of carp and sterlet spermatozoa after motility activation may reflect an activation of signaling pathways involved in gamete fusion and fertilization.

Involvement of multiple phospho-proteins in spermatozoa motility of carp and sterlet indicates a complex network of signaling molecules and enzymes involved in sperm motility activation, regulation and fertilization. This work has set the stage for future studies by identifying the major phospho-proteins whose functions should be analyzed in detail.

\section{Supplementary data}

This is linked to the online version of the paper at http://dx.doi.org/10.1530/REP-16-0662.

\section{Declaration of interest}

The authors declare that there is no conflict of interest that could be perceived as prejudicing the impartiality of the research reported.

\section{Funding}

Support for this research was provided by the Ministry of Education, Youth and Sports of the Czech Republic - projects 'CENAKVA' (No. CZ.1.05/2.1.00/01.0024), 'CENAKVA II' (No. LO1205 under the NPU I program), COST Association (No. LD14119, and Food and Agriculture COST Action STSM-FA1205-16781), the Grant Agency of the University of South Bohemia in Ceske Budejovice (No. $114 / 2013 / Z$ and $016 / 2014 / Z$ ), and by the Czech Science Foundation (No. P502/12/1973 and P502/15-12034S). This study was also funded by the National Science Centre, Poland (2016/21/B/NZ9/03620).

\section{Acknowledgements}

The authors acknowledge the Laboratory of Reproductive Physiology, University of South Bohemia in České Budějovice, Faculty of Fisheries and Protection of Waters, especially Borys Dzyuba and Marek Rodina. They also acknowledge P. Huitorel for helpful discussion.

\section{References}

Aitken RJ \& Nixon B 2013 Sperm capacitation: a distant landscape glimpsed but unexplored. Molecular Human Reproduction 19 785-793. (doi:10.1093/molehr/gat067)

Aitken RJ, Paterson M, Fisher H, Buckingham DW \& van Duin M 1995 Redox regulation of tyrosine phosphorylation in human spermatozoa and its role in the control of human sperm function. Journal of Cell Science 108 2017-2025.

Alavi SMH \& Cosson J 2006 Sperm motility in fishes. (II) Effects of ions and osmolality: a review. Cell Biology International 30 1-14. (doi:10.1016/j. cellbi.2005.06.004)

Alavi SMH, Gela D, Rodina M \& Linhart O 2011 Roles of osmolality, calcium - potassium antagonist and calcium in activation and flagellar beating pattern of sturgeon sperm. Comparative Biochemistry and Physiology Part A 160 166-174. (doi:10.1016/j.cbpa.2011.05.026)

Baker MA 2016 Proteomics of post-translational modifications of mammalian spermatozoa. Cell and Tissue Research 363 279-287. (doi:10.1007/s00441-015-2249-x)

Billard R, Cosson J, Fierville F, Brun R, Rouault T \& Williot P 1999 Motility analysis and energetics of the Siberian sturgeon Acipenser 
baerii spermatozoa. Journal of Applied IChthyology 15 199-203. (doi:10.1111/j.1439-0426.1999.tb00234.x)

Bondarenko O, Dzyuba B, Cosson J, Yamaner G, Prokopchuk G, Psenicka M \& Linhart O 2013 Volume changes during the motility period of fish spermatozoa: interspecies differences. Theriogenology 79 872-881. (doi:10.1016/j.theriogenology.2013.01.005)

Breitbart H \& Naor Z 1999 Protein kinases in mammalian sperm capacitation and the acrosome reaction. Reviews of Reproduction 4 151-159. (doi:10.1530/ror.0.0040151)

Brokaw CJ 1987 A lithium-sensitive regulator of sperm flagellar oscillation is activated by cAMP-dependent phosphorylation. Journal of Cell Biology 105 1789-1798. (doi:10.1083/jcb.105.4.1789)

Caillard O, Moreno H, Schwaller B, Llano I, Celio MR \& Marty A 2000 Role of the calcium-binding protein parvalbumin in short-term synaptic plasticity. PNAS 97 13372-13377. (doi:10.1073/pnas.230362997)

Cohen G, Rubinstein S, Gur Y \& Breitbart H 2004 Crosstalk between protein kinase $\mathrm{A}$ and $\mathrm{C}$ regulates phospholipase $\mathrm{D}$ and $\mathrm{F}$-actin formation during sperm capacitation. Developmental Biology 267 230-241. (doi:10.1016/j.ydbio.2003.10.034)

Cole JA \& Meyers SA 2011 Osmotic stress stimulates phosphorylation and cellular expression of heat shock proteins in rhesus macaque sperm. Journal of Andrology 32 402-410. (doi:10.2164/jandrol.110.010702)

Cosson MP \& Gagnon C 1988 Protease inhibitors and substrates block motility and microtubule sliding of sea urchin and carp spermatoza. Cell Motility and the Cytoskeleton 10 518-527. (doi:10.1002/cm.970100408)

Dietrich MA, Dietrich GJ, Mostek A \& Ciereszko A 2016 Motility of carp spermatozoa is associated with profound changes in the sperm proteome. Journal of Proteomics 138 124-135. (doi:10.1016/j.jprot.2016.02.029)

Dzyuba B, Bondarenko O, Fedorov P, Gazo I, Prokopchuk G \& Cosson J 2015 Energetics of fish spermatozoa: the proven and the possible. Aquaculture (in press). (doi:10.1016/j.aquaculture.2016.05.038)

Dzyuba V, Dzyuba B, Cosson J \& Rodina M 2016 Enzyme activity in energy supply of spermatozoon motility in two taxonomically distant fish species (sterlet Acipenser ruthenus, Acipenseriformes and common carp Cyprinus carpio, Cypriniformes). Theriogenology 85 567-574. (doi:10.1016/j.theriogenology.2015.09.040)

Gazo I, Shaliutina-Kolesova A, Dietrich MA, Linhartová P, Shaliutina O \& Cosson J 2015 The effect of reactive oxygen species on motility parameters, DNA integrity, tyrosine phosphorylation and phosphatase activity of common carp (Cyprinus carpio L.) spermatozoa. Molecular Reproduction and Development 82 48-57. (doi:10.1002/mrd.22442)

Hamasaki T, Barkalow K, Richmond J \& Satir P 1991 cAMP-stimulated phosphorylation of an axonemal polypeptide that copurifies with the $22 \mathrm{~S}$ dynein arm regulates microtubule translocation velocity and swimming speed in Paramecium. PNAS 88 7918-7922. (doi:10.1073/ pnas.88.18.7918)

Hayashi H, Yamamoto K, Yonekawa H \& Morisawa M 1987 Involvement of tyrosine protein kinase in the initiation of flagellar movement in rainbow trout spermatozoa. Journal of Biological Chemistry 262 16692-16698.

Herbert JM, Augereau JM, Gleye J \& Maffrand JP 1990 Chelerythrine is a potent and specific inhibitor of protein kinase C. Biochemical and Biophysical Research Communications 172 993-999. (doi:10.1016/0006291X(90)91544-3)

Huttemann M, Lee I, Samavati L, Yu H \& Doan JW 2007 Regulation of mitochondrial oxidative phosphorylation through cell signaling. Biochimica et Biophysica Acta 1773 1701-1720. (doi:10.1016/j. bbamcr.2007.10.001)

Inaba K 2003 Molecular architecture of the sperm flagella: molecules for motility and signaling. Zoological Science 20 1043-1056. (doi:10.2108/ zsj.20.1043)

Inaba K, Morisawa S \& Morisawa M 1998 Proteasomes regulate the motility of salmonid fish sperm through modulation of cAMP-dependent phosphorylation of an outer arm dynein light chain. Journal of Cell Science 111 1105-1115.

Inaba K, Kagami O \& Ogawa K 1999 Tctex2-related outer arm dynein light chain is phosphorylated at activation of sperm motility. Biochemical and Biophysical Research Communications 256 177-183. (doi:10.1006/ bbrc.1999.0309)

Itoh A, Inaba K, Ohtake H, Fujinoki M \& Morisawa M 2003 Characterization of a cAMP-dependent protein kinase catalytic subunit from rainbow trout spermatozoa. Biochemical and Biophysical Research Communications 305 855-861. (doi:10.1016/S0006-291X(03)00840-4)
Kakar M, Kanwal C, Davis JR, Li H \& Lim CS 2006 Geldanamycin, an inhibitor of Hsp90, blocks cytoplasmic retention of progesterone receptors and glucocorticoid receptors via their respective ligand binding domains. AAPS Journal 8 E718-E728. (doi:10.1208/aapsj080481)

Kalina M, Socher R, Rotem R \& Naor Z 1995 Ultrastructural localization of protein kinase $\mathrm{C}$ in human sperm. Journal of Histochemistry and Cytochemistry 43 439-445. (doi:10.1177/43.4.7897184)

Kohr MJ, Traynham CJ, Roof SR, Davis JP \& Ziolo MT 2010 cAMPindependent activation of protein kinase $\mathrm{A}$ by the peroxynitrite generator SIN-1 elicits positive inotropic effects in cardiomyocytes. Journal of Molecular and Cellular Cardiology 48 645-648. (doi:10.1016/j. yjmcc.2010.01.007)

Krasznai Z, Marian T, Izumi H, Damjanovich S, Balkay L, Tron L \& Morisawa M 2000 Membrane hyperpolarization removes inactivation of $\mathrm{Ca}^{2+}$ channels, leading to $\mathrm{Ca}^{2+}$ influx and subsequent initiation of sperm motility in the common carp. PNAS 97 2052-2057. (doi:10.1073/ pnas.040558097)

Lark DS, Reese LR, Ryan TE, Torres MJ, Smith CD, Lin CT \& Neufer PD 2015 Protein kinase a governs oxidative phosphorylation kinetics and oxidant emitting potential at complex I. Frontiers in Physiology 6332.

Lasko J, Schlingmann K, Klocke A, Mengel GA \& Turner R 2012 Calcium/ calmodulin and CAMP/protein kinase-A pathways regulate sperm motility in the stallion. Animal Reproduction Science 132 169-177. (doi:10.1016/j.anireprosci.2012.05.007)

Li K, Xue Y, Chen A, Jiang Y, Xie H, Shi Q, Zhang S \& Ni Y 2014 Heat shock protein 90 has roles in intracellular calcium homeostasis, protein tyrosine phosphorylation regulation, and progesterone-responsive sperm function in human sperm. PLOS ONE 9 e115841. (doi:10.1371/journal. pone.0115841)

Lindemann CB \& Kanous KS 1989 Regulation of mammalian sperm motility. Archives of Andrology 23 1-22. (doi:10.3109/01485018908986783)

Linhart O, Cosson J, Mims SD, Shelton WL \& Rodina M 2002 Effects of ions on the motility of fresh and demembranated paddlefish (Polyodon spathula) spermatozoa. Reproduction 124 713-719. (doi:10.1530/ rep.0.1240713)

Mizrahi R \& Breitbart H 2014 Mitochondrial PKA mediates sperm motility. Biochimica et Biophysica Acta 1840 3404-3412. (doi:10.1016/j. bbagen.2014.09.005)

Morita M, Takemura A \& Okuno M 2003 Requirement of $\mathrm{Ca}^{2+}$ on activation of sperm motility in euryhaline tilapia Oreochromis mossambicus. Journal of Experimental Biology 206 913-921. (doi:10.1242/jeb.00153)

Morita M, Takemura A, Nakajima A \& Okuno M 2006 Microtubule sliding movement in tilapia sperm flagella axoneme is regulated by $\mathrm{Ca}^{2+} /$ calmodulin-dependent protein phosphorylation. Cell Motility and the Cytoskeleton 63 459-470. (doi:10.1002/cm.20137)

Newton AC 1995 Protein kinase C: structure, sunction, and regulation. Journal of Biological Chemistry 270 28495-28498. (doi:10.1074/ jbc.270.48.28495)

Nixon B, Anderson AL, Smith ND, McLeod R \& Johnston SD 2016 The Australian saltwater crocodile (Crocodylus porosus) provides evidence that the capacitation of spermatozoa may extend beyond the mammalian lineage. Proceedings of the Royal Society B 283. (doi:10.1098/rspb.2016.0495)

Nomura M, Inaba K \& Morisawa M 2000 Cyclic AMP- and calmodulindependent phosphorylation of 21 and 26 kda proteins in axoneme is a prerequisite for SAAF-induced motile activation in ascidian spermatozoa. Development, Growth and Differentiation 42 129-138. (doi:10.1046/ j.1440-169x.2000.00489.x)

Nomura M, Yoshida M \& Morisawa M 2004 Calmodulin/calmodulindependent protein kinase II mediates SAAF-induced motility activation of ascidian sperm. Cell Motility and the Cytoskeleton 59 28-37. (doi:10.1002/cm.20020)

O'Flaherty C, de Lamirande E \& Gagnon C 2006 Reactive oxygen species modulate independent protein phosphorylation pathways during human sperm capacitation. Free Radical Biology and Medicine 40 1045-1055. (doi:10.1016/j.freeradbiomed.2005.10.055)

Perchec G, Jeulin C, Cosson J, André F \& Billard R 1995 Relationship between sperm ATP content and motility of carp spermatozoa. Journal of Cell Science 108 747-753.

Perchec Poupard G, Gatti JL, Cosson J, Jeulin C, Fierville F \& Billard R 1997 Effects of extracellular environment on the osmotic signal 
transduction involved in activation of motility of carp spermatozoa Journal of Reproduction and Fertility 110 315-327. (doi:10.1530/ jrf.0.1100315)

Ray PD, Huang BW \& Tsuji Y 2012 Reactive oxygen species (ROS) homeostasis and redox regulation in cellular signaling. Cell Signaling $\mathbf{2 4}$ 981-990. (doi:10.1016/j.cellsig.2012.01.008)

Riento K, Frick M, Schafer I \& Nichols BJ 2009 Endocytosis of flotillin-1 and flotillin-2 is regulated by Fyn kinase. Journal of Cell Science $\mathbf{1 2 2}$ 912-918. (doi:10.1242/jcs.039024)

Satouh Y, Padma P, Toda T, Satoh N, Ide H \& Inaba K 2005 Molecular characterization of radial spoke subcomplex containing radial spoke protein 3 and heat shock protein 40 in sperm flagella of the ascidian Ciona intestinalis. Molecular Biology of the Cell 16 626-636. (doi:10.1091/mbc.E04-09-0784)

Spiliotis ET 2010 Regulation of microtubule organization and functions by septin GTPases. Cytoskeleton 67 339-345. (doi:10.1002/cm.20448)

Takei GL, Mukai C \& Okuno M 2012 Transient $\mathrm{Ca}^{2+}$ mobilization caused by osmotic shock initiates salmonid fish sperm motility. Journal of Experimental Biology 215 630-641. (doi:10.1242/jeb.063628)

Tash JS \& Means AR 1982 Regulation of protein phosphorylation and motility of sperm by cyclic adenosine monophosphate and calcium. Biology of Reproduction 26 745-763. (doi:10.1095/biolreprod26.4.745)

Tash JS, Krinks M, Patel J, Means RL, Klee CB \& Means AR 1988 Identification, characterization, and functional correlation of calmodulin-dependent protein phosphatase in sperm. Journal of Cell Biology 106 1625-1633. (doi:10.1083/jcb.106.5.1625)

Urner F \& Sakkas D 2003 Protein phosphorylation in mammalian spermatozoa. Reproduction 125 17-26. (doi:10.1530/rep.0.1250017) van Gestel RA, Brewis IA, Ashton PR, Helms JB, Brouwers JF \& Gadella BM 2005 Capacitation-dependent concentration of lipid rafts in the apical ridge head area of porcine sperm cells. Molecular Human Reproduction 11 583-590. (doi:10.1093/molehr/gah200)

Visconti PE, Moore GD, Bailey JL, Leclerc P, Connors SA, Pan D, OldsClarke P \& Kopf GS 1995 Capacitation of mouse spermatozoa. II. Protein tyrosine phosphorylation and capacitation are regulated by a cAMP-dependent pathway. Development 121 1139-1150.

White D, de Lamirande E \& Gagnon C 2007 Protein kinase C is an important signaling mediator associated with motility of intact sea urchin spermatozoa. Journal of Experimental Biology 210 4053-4064. (doi:10.1242/jeb.007013)

Zilli L, Schiavone R, Storelli C \& Vilella S 2008 Molecular mechanisms determining sperm motility initiation in two sparids (Sparus aurata and Lithognathus mormyrus). Biology of reproduction 79 356-366. (doi:10.1095/biolreprod.108.068296)

Zilli L, Schiavone R \& Vilella S 2016 Role of protein phosphorylation/ dephosphorylation in fish sperm motility activation: state of the art and perspectives. Aquaculture (in press). (doi:10.1016/j. aquaculture.2016.03.043)

Received 14 December 2016

First decision 30 January 2017

Revised manuscript received 17 August 2017

Accepted 29 August 2017 